\title{
DLHÁ CESTA K PRÁ VNEJ EMANCIPÁCII ŽENY V RODINNÝCH A MAJETKOVÝCH VZŤAHOCH
}

\author{
MIRIAM L A C L A V ÍK O V Á - ADRIANA Š V E C O V Á
}

LACLAVÍKOVÁ, Miriam - ŠVECOVÁ, Adriana. The long road to the legal emancipation of women in family and property relations. Historický časopis, 2018, roč. 66, č. 4, pp. 599-628. Bratislava.

The authors discuss the legal emancipation of the Slovak or Hungarian woman in family and property relations (as both these relations determine the status of each human individual) which took place in two stages; Firstly, it was while the first original medieval law, which was preserved even in the modern concept of the patriarchal family and subordinate position of women, was effective. Secondly, it was during the century when modern law was born, namely from 1848 to 1948 , when women became independent and emancipated in both social and legal relations. The authors identify the key legal norms that helped to create and configure the milestones on the slow and long road to female emancipation and transformation of the social and legal awareness of Slovak society. The ambition of the authors is to point out the general conclusions about the status of Slovak woman, reached after reviewing the legal norms, court decisions and jurisprudence.

Key words: Woman. Law. Status. Property Rights. Emancipation. Women's Rights. Gender Equality. Equality of Rights. Kingdom of Hungary. Czechoslovak Republic.

DOI: https://doi.org/10.31577/histcaso.2018.66.4.2

\section{Úvod}

Pre vytýčenú tému právneho postavenia ženy sme zvolili právne východisko pôvodnej právnej úpravy $\mathrm{v}$ určených súkromnoprávnych odvetviach rodinného a majetkového statusu, ${ }^{1}$ a preto $\mathrm{z}$ dôvodu ich stáročnej právnej stability a nemennosti sa dotýkame stredovekého obyčajového práva s jeho základom v Tripartite ${ }^{2}$

1 Pozornost' venujeme výhradne postaveniu ženy v súkromnoprávnych vzt'ahoch, pretože tu mala svoje dôstojné miesto. Naopak, jej výrazne slabú, marginalizovanú verejnoprávnu pozíciu a málo preskúmanú priamu spoločensko-politickú aktivitu si nevšímame.

2 Ďalej len Trip. Ide o najvýznamnejšiu súkromnú kompilačnú zbierku šlachtického obyčajového práva, autorizovanú protonotárom Král’ovskej kúrie Štefanom Werbőczym, ktorý ju pripravil ako návrh zákona na snem v roku 1514. Zhodou nešt’astných a dnes už neidentifikovatel'ných okolností sa zákonom nestala, ale nadobudla silu písanej právnej obyčaje s klúčo- 
a prijatia následných novovekých právnych úprav (zväčša kozmetických v novovekých zákonných úpravách). Úvodná kapitola z lineárne chronologického uhla pohl'adu je preto nevyhnutná ako východisková právna kontrapozícia pôvodného všeobecného spoločensko-právneho postavenia (statusu) ženy ako stavovsky viazanej a právom viac obmedzovanej bytosti. ${ }^{3}$ Pokúsime sa pritom o nie príliš zat’ažujúci, ale výstižný exkurz do starších dejín stredoveku a novoveku, ktorý nám umožní reálnejšie pochopenie nižšie uvedených prevratných transformácií právneho postavenia žien, zasadených vo svojej podstate do tzv. dlhého 19. storočia, na bytost' stavom viazanú zväčša len s ohl'adom na spoločenskú konvenciu a mrav a budujúcu si svoje miesto $\mathrm{v}$ meniacich sa podmienkach liberálneho a industriálneho sveta. ${ }^{4}$ Okrem toho v nej v krátkosti definujeme a explikujeme viaceré právne inštitúty, ktoré patrili do právnej „výbavy“ ženy v staršom aj no-

vým postavením $\mathrm{v}$ uhorských právnych prameňoch.

V štúdii vychádzame z nasledujúcich vydaní diela Opus Tripartitum: MÁRKUS, Desző (ed.). Corpus iuris Hungarici. Editio millennaria memorabilis. Opus Tripartitum Stephani de Werböcz. Lipsiae: Sumptibus Duncker \& Humbolt, 1902; BAK, János - BANYÓ, Péter - RADY, Martyn (ed. and trans.). Stephen Werböczy: The customary Law of the Renowned Kingdom of Hungary in Three Parts (1517). Budapešt': Charles Schlacks, Jr., Idyllwild CA, CEU, 2005. ISBN 1884445403.

3 K ženskej otázke $\mathrm{v}$ širších európskych reáliách možno napríklad spomenút' práce: DUBY, George - PERROT, Michelle (eds.). Geschichte der Frauen. Frankfurt; New York: Campus Verlag, 1993. ISBN 3596140315; ENNENOVÁ, Edith. Ženy ve středověku. Praha: Argo, 2001. ISBN 8072033697; BASTL, Beatrix. Tugend, Liebe, Ehre. Die adelige Frau in der Frühen Neuzeit. Wien: Böhlau Verlag, 2000. ISBN 3205992334; GERHARD, Ute (ed.). Frauen in der Geschichte des Rechts. Von der Frühen Neuzeit bis zur Gegenwart. München: C.H.Beck, 1997. ISBN 9783406428661; LENGYELOVÁ, Tünde (ed.). Žena a právo. Právne a spoločenské postavenie žien v minulosti. Bratislava: Academic Electronic Press, s. r. o., 2004. ISBN 8088880599; BARDSLEY, Sandy. Women 's Roles in the Middle Ages. Porthsmouth: Greenwood Press, 2007. ISBN 9780313336355; MITCHELL, Elisabeht Linda. Family Life in the Middle Ages. London: Greenwood Press, 2007. ISBN 9780313336300 a i. Z novších prác slovenskej proveniencie pozri HUDÁČEK, Pavol. Právne postavenie vdovy v stredovekom Uhorsku do roku 1222 a otázka venného. In Historický časopis, 2013, roč. 61, č. 2, s. 227-262. ISSN 0018-2575.

4 V najstarších dochovaných právnych textoch vzt’ahujúcich sa k nášmu územiu (Súdny zákon pre laikov; Ustanovenia sv. otcov) sa žena spomínala najčastejšie v dvoch súvislostiach: prvou je oblast' trestného práva (žena ako páchatel' trestného činu (smilstvo, smrt' novorodenca, potrat) alebo obet' (znásilnenie); a druhou oblast' manželského práva (monogamia, manželské prekážky, nerozlučitel'nost' manželstva). V zákonných úpravách panovníkov z rodu Arpádovcov (zákony sv. Štefana (II/24 § 2; II/28), zákony sv. Ladislava, Zlatá bula Ondreja II.) sa formoval majetkovoprávny status ženy, ktorý sa pre celý stredovek stal určujúcim vo vzt’ahu k vymedzeniu jej právnej spôsobilosti (vdovské právo, obvenenie, parafernálny majetok) a smeroval k stanoveniu osobitných tzv. ženských práv (dekréty Žigmunda Luxemburského, Mateja I. a Vladislava II. Jagellonského). Súčasne sa v súvislosti so ženou kreovala požiadavka manželskej vernosti a trestný čin cudzoložstva (zákony sv. Ladislava a Kolomana). 
vodobom práve, ergo uvedená rigidita pôvodnej úpravy súkromnoprávneho postavenia žien až do roku 1848/49 len zvýrazní následne revolučný prerod v práve naviazaný na rôznorodé emancipačné pohyby v Európe merôsmych rokov, ktoré ovplyvnili aj právny a spoločenský status žien a v jeho rámci predovšetkým jej postavenie v osobnoprávnych a majetkovoprávnych vzt’ahoch. Revolučný však bol len čo do obsahu (z hl'adiska materiálneho dal právu novodobý obsah), ale nie čo do vzniku a uvádzania nového práva do života a preto, hoci ide $\mathrm{v}$ porovnaní s predchádzajúcim stredoveko-novovekým právnym vývojom o zrýchlenú konverziu, aj táto sa udiala pozvol'ne, etapovito a po prijatí následných zákonných kodifikácií, ktoré z hl'adiska časového vyplnili celú druhú polovicu 19. storočia. $^{5}$

\section{Status ženy v staršom uhorskom práve}

V stredoveko-novovekej spoločnosti predstavovala najdôležitejšie kritérium determinujúce sociálne postavenie jednotlivca (tak muža, ako aj ženy) príslušnost' k stavu, s obmedzenými možnost’ami sociálnej mobility. ${ }^{6}$ Ďalšími relevantnými faktormi určujúcimi postavenie jednotlivca v spoločnosti a vplývajúcimi na rozsah spôsobilosti na právne úkony ${ }^{7}$ boli: vek, zdravie, pohlavie, rodinný stav, ${ }^{8}$ márnotratnost', občianska čest', náboženstvo, štátna príslušnost' a povolanie. Pri charakteristike právnej a sociálnej pozície ženy staršie právo vychádzalo z jej troch určujúcich spoločenských rolí: panenstva, manželstva a vdovstva. ${ }^{9}$ Manželstvo sa prioritne spájalo s biologickou funkciou ženy a pohl'ad spoločnosti

5 Vychádzame zo zásadného historického faktora postupnosti a plynulosti evolučných zmien v práve, ktoré progredujú obvykle nenápadne, plazivo, no priamočiaro a ireverzibilne.

6 DUDEKOVÁ, Gabriela - LENGYELOVÁ, Tünde. Rodová identita v historickej perspektíve. In KILIÁNOVÁ, Gabriela - KOWALSKÁ, Eva - KREKOVIČOVÁ, Elena (eds.). My a tí druhi v modernej spoločnosti. Konštrukcie a transformácie kolektívnych entít. Bratislava: VEDA, Vydavatel'stvo SAV, 2009, s. 45. Pozri aj RYANTOVÁ, Marie. Život ranně novověké šlechtičny v Českém království (právní limity a skutečné možnosti). In LENGYELOVÁ, Tünde (ed.). Žena a právo. Právne a spoločenské postavenie žien v minulosti. Bratislava: Academic Electronic Press, s. r. o., 2004, s. 106. ISBN 8088880599.

7 Štefan Luby tieto podmienky chápe ako stavy vplývajúce na spôsobilost' na právne úkony (t. j. spôsobilost' vlastným konaním nadobúdat' práva a povinnosti a niest' právnu zodpovednost' za protiprávne konanie) = tzv. statusové vlastnosti a stavy. LUBY, Štefan. Dejiny súkromného práva na Slovensku. 2. vyd. Bratislava: Iura Edition, 2002, s. 166-167. ISBN 8088715806.

8 „Středověký člověk nemá vůbec smysl pro svobodu v moderním chápání toho slova. ... Jednotlivec ve středověké západni Evropě patřil predevším k rodině. Rodina je rozsáhlá, patriarchální nebo kmenová. Pod vedením hlavy rodiny jednotlivce potlačuje, vnucuje mu vlastnictví, odpovédnost, kolektivní činnost “ a ženám aj ochranu (pozn. aut.). Le GOFF, Jacques. Kultura středověké Evropy. Praha: Vyšehrad 2005, s. 377. ISBN 8070218088.

9 KRÁL, Pavel. Vdovy ve šlechtické společnosti ranného novověku. In LENGYELOVÁ, ref. 6, s. 142. 
na vdovstvo zostal rozporuplný: na jednej strane ideál cnostnej vdovy žijúcej na majetkoch zomrelého manžela spolu s det'mi a na druhej strane realita pomerne bezmocnej ovdovenej ženy odkázanej na milost' a podporu zo strany rodiny. ${ }^{10}$ Právny a širší spoločenský pohl'ad na ženu vychádzal z rámca väčšinového krest'anského náboženstva, a preto zásadným bolo jej materské poslanie s ciel'om zabezpečenia dedičov a ruka $\mathrm{v}$ ruke $\mathrm{s}$ tým praktické hospodárske kompetencie (vedenie domácnosti, resp. dozeranie na chod domácnosti, starostlivost' o (najmä malé) deti).

Stredoveko-novoveké právo obsiahnuté v Tripartite vo všeobecnosti vychádzalo z primárnej zásady, že medzi mužským a ženským pohlavím ${ }^{11}$ prirodzene existuje výrazná právna rozdielnost' (diversitas iurium), ${ }^{12} \mathrm{~s}$ čím súvisel aj rozdielny rozsah práv a povinností viažucich sa $\mathrm{k}$ jednému alebo druhému pohlaviu. ${ }^{13}$ Novoveká právna veda túto diversitas iurium prebrala, akceptovala a rozvinula. Pregnantne to vyjadril Pavol Szlemenicz, podla ktorého:

„Pohlavie vytvára podl'a našich zákonov nemálo rozdielov v práve. Totiž,

1. pretože Trip. I/čl. 18 deklaruje záväzok obrany krajiny, z ktorého sa odvodzuje nárok na vlastnicke právo k nehnutel'nostiam, ktoré nie sú ženy schopné vykonávat' (foeminae satisfacere nequeunt), preto nemajú dedičské právo k týmto nehnutel'nostiam. ${ }^{14}$

10 Slobodné postavenie vdovy (často nútenej uzavriet' nové manželstvo alebo vstúpit’ do kláštora) bolo totiž zväčša vnímané ako „nezdravá ženská sloboda“, ktorá mala byt' v konečnom dôsledku kontrolovaná a usmerňovaná. HUDÁČEK, ref. 3, s. 234.

11 V stredoveku sa rozdiely medzi pohlaviami zdôvodňovali aj etymologicky. Izidor zo Sevilly vo svojej Etymologickej encyklopédii spájal termín muž, lat. vir s virtus (lat. zdatnost', cnost') a termín žena, lat. mulier s mollitia (lat. slabost', nežnost'). GOETZ, Hans Werner. Život ve středověku. München: C.H. Beck, 1996. Preklad Milan Váňa. Jičany: Nakladatelství H+H Vyšehradská, s.r.o., 2005, s. 70. ISBN 8073190257.

12 Pozri aj KADLEC, Karel. Verböczyovo Tripartitum a soukromé právo uherské a chorvatské šlechty v něm obsažené. Praha: Nákladem České akademie císaře Františka Jozefa pro vědy, slovesnost a umění, 1902, s. 146. Na počiatku 19. storočia uznal I. Kelemen právnu rôznost' pohlaví: ,, diversitas personarum ratione status naturalis “. In KELEMEN, Emericus. Institutiones juris Hungarici privati. Liber I. De personis. Budae: Typis regiae scientiarum universitatis Hungaricae, 1818, s. 157.

13 Uvedenú rozdielnost' ako prirodzenú vnímalo aj rímske právo. Porovnaj konštatovanie rímskeho právnika Papiniána (Pap. D. 1, 5, 9): „In multis iuris nostri articulis deterior est condicio feminarum quam masculorum. “ Nerovnoprávne postavenie ženy charakterizovalo aj rodinné právo antického Grécka. Pozri bližšie VYŠNÝ, Peter - PÚCHOVSKÝ, Ján - ŠOŠKOVÁ, Ivana. Svetové dejiny štátu a práva. Trnava: Typi Universitatis Tyrnaviensis, 2013, s. 71. ISBN 9788080827335.

14 Szlemenicz pokračuje: ,s výnimkou výslovne určenej doložky utriusque sexus, alebo ak ide o majetky nadobudnuté otcom za peniaze (t. j. samostatne nadobudnutý majetok), alebo ide o majetok dievčenskej štvrtiny alebo majetok nadobudnutý ako homágium za zabitého šlachtica (k tomu pozri Trip. I/čl. 17,18, 48, 102) “. SZLEMENICZ, Paulus. Elementa iuris hungarici 
2. Ked’že ženy neudržiavajú/nezachovávajú rodinu, potomkovia nesú meno, predikát, šlachtictvo a iné rodinné tituly a pocty nie po matke, $s$ výnimkou úkonu praefekcie, ${ }^{15}$ ale po otcovi (Trip. I/čl. 7, 22 \& 3, 51 § 3).

3. Kvôli ich slabosti musia byt'ženy trvalo podriadené moci poručníka, dokial' sa nevydajú a podl'a Trip. čl. 112 sú viac alebo menej podriadené poručníckej moci iných. ${ }^{16}$

4. D̆alej z dôvodu, že kedysi, ak bol muž odsúdený za vlastizradu na stratu hlavy a celého majetku, ženy tento trest nepodstupovali (foemina in capitali sententia non convincebatur). Podl'a Trip. II/čl. 42 a 43.

5. Z dôvodu existencie mužov nedržia (nechránia) ženy rodinné dokumenty, avšak z dokumentov s doložkou utriusque sexus môžu žiadat' od bratov odpisy (Trip. II/čl. 42),

6. konečne, osobne sa nezúčastňujú župných kongregácií, ale prostrednictvom svojich vyslancov. Vo veci šlachtickej insurekcie a všetkých verejných mužských funkcii sa zachováva znenie zák. čl. 55/1662 a 63/1741 § 3. "17

Mužské pohlavie, vtesnané do medzí krest’anstvom determinovaného patriarchátu, ktorý existoval tak vo verejnej, ako aj súkromnej sfére a hierarchizoval právnu a spoločenskú moc muža nad ženou, sa vo všeobecnosti súdobo označovalo termínom sexus dignior (lepšie, dôstojnejšie pohlavie). Z uvedeného vychádzala i stereotypná predstava ideálneho vzt’ahu muža a ženy, $v$ rámci ktorej vyplývala pre muža povinnost' zabezpečit' starostlivost' a ochranu o ,zverenú ženu“, ale aj o jej majetok, ${ }^{18}$ ktorý by sa často ,,pre slabost' a nestálost' ženského pohlavia “(imbecillitas et infirmitas sexus) $)^{19}$ a ,pre svoju l'ahkomysel'nú povahu“

privati. I. tomus, Posonii, 1829, s. 58.

15 Právny úkon udelenia majetku, pôvodne určeného len mužom, pokial' mužská vetva vymrela, určeného žene (dcére) a jej potomstvu, ktorá nastupovala do postavenia mužského dediča (čiže sa „pochlapčila“). Štefan Luby hovorí dokonca pri prefekcii nenáležite o istom zrovnoprávnení žien s mužmi. In LUBY, ref. 7, s. 170, 397-398.

16 Ďalej P. Szlemenicz pokračuje: „Z tohto pravidla je vylúčená matka podl’a Trip. I/čl. 115, ktorá kompenzuje svoju ženskú slabost' materskou láskou. " SZLEMENICZ, ref. 14, s. 58.

17 SZLEMENICZ, ref. 14, s. 58. Na uvedené právne diferenciácie poukazujú a sumarizujú ich G. Dudeková a T. Lengyelová, a zároveň prízvukujú, že osvietenské právo konzervovalo daný model hierarchicky usporiadaného vzt'ahu muža a ženy, v ktorom bola žene určená nezastupitel'ná tradičná rola v rodine ako matky a manželky. In DUDEKOVÁ - LENGYELOVÁ, ref. 6, s. 48-56.

18 Porovnaj tvrdenie v Trip. I/113 § 4: ,successio bonorum sit causa tutelarum “.

19 SÓJKA-ZIELIŃSKA, Katarzyna. Historia prawa. Warszawa: Wydawnictwo Naukowe PWN, 1993, s. 98. ISBN 9788326493508. Pozri bližšie aj KOCH, Elisabeht. Die Frau im Recht der Frühen Neuzeit. Juristische Lehren und Begründungen. In GERHARD, ref. 3, s. 83. 
a ,jednoduché zmýšlanie “20 mohol zmenšit' alebo stratit'. Avšak komplementárne k starostlivosti muža o ženu musíme taktiež pripomenút', že jej postavenie v práve charakterizoval aj istý protekcionizmus „slabšieho“ ženského pohlavia v nadväznosti na miesto ženy v spoločenskom rebríčku (osobitné dedičské nároky (quarta puellaris), právo na bývanie v otcovskom dome a stavu primeranú výbavu v prípade uzavretia manželstva (ius capillare) a pod.).

$\mathrm{V}$ typických súkromnoprávnych oblastiach rodinného a vecného (osobitne manželského majetkového) práva sa viac-menej uplatňoval stáročiami budovaný primárny, podriadený status ženy v patriarchálnom type práva, ${ }^{21}$ zachovaný až do neskorého novoveku (t. j. do obdobia pred revolúciou 1848/49). Poukážeme však na niektoré zrovnoprávňujúce zmeny pozvol'na kreované počas stredoveku a novoveku, s bližším určením právneho postavenia ženy v novoveku na podklade diel novovekej (najmä osvietenstvom ovplyvnenej) právnej vedy, ohlasujúcej budúcu a vel'mi pomaly, zásadne evolučne prijímanú emancipáciu ženy vo vybraných odvetviach práva. Ved' len napríklad v procesnom práve, ktoré dlhodobo odmietalo svedectvá žien, dosiahla novoveká žena viac-menej rovnocenné postavenie s mužom. ${ }^{22}$

V osobnom práve bola žena po celý stredovek a ešte aj v neskorom novoveku podriadená zákonnej moci otca, následne manžela alebo poručníka. Dôkaz o tom podáva rešpektovaný novoveký právnik a civilista 18. storočia Š. Huszty, ked' nadväzuje na Trip. I/čl. $112^{23}$ a hovorí: ,že dievčatá zotrvajú pod poručníckou mocou dovtedy, dokial' sa nevydajú (quamdiu viro nupserint) ... a pokial' tak neučinia, zotrvajú v ňom, pretože pre ich l'ahkovážnu povahu môžu byt' l'ahko podvedené". Všeobecné obmedzenie spôsobilosti žien na právne úkony sa v stredoveko-novovekom myslení spájalo s potrebou ich ochrany, ktorá sa mala zabezpečit' ich podriadením už zmienenej otcovskej moci, moci poručníka či manžela. ${ }^{24}$ Avšak d’alší uhorskí právni vedci už reagovali na novovekú právnu

20 Porovnaj Trip. I/112 § 1 „Nam puellae aliter, carentes tutore, ipsae ex ingenii earum levitate facile seduci, decipique possent. “ Tripartitum I/91 „,quia puellae plerumque animi levitate seducuntur".

21 Ide primárne o antropologický či sociologický, nie o právnohistorický konštrukt a termín.

22 Dlhodobo pertraktovanú otázku povolit' či nepovolit' svedeckú účast' (predovšetkým pri zriadení závetov) ženám uhorská novoveká právna veda 18. storočia vyriešila nakoniec v ich prospech. KHLOSZ, Paulus. Praxis seu forma processualis fori spiritualis in Mariano Apostolico Hungariae regno usu recepta. Tyrnaviae: Typis academicis Societatis Jesu, 1761, s. 237; podobne KELEMEN, Emericus. Institutiones juris Hungarici privati. Liber II. De personis. Budae : Typis regiae scientiarum universitatis Hungaricae, 1818, s. 327; KÖVY, Alexander. Summarium elementorum iurisprudentiae Hungaricae. S. Patakani: Impressum per Andream Nádashey, 1822, s. 99.

23 Trip. I/čl. 112: „Vieme, že nevydaté panny a dievčatá sú vždy pod poručníctvom a v moci iného, lebo ak by poručníka nemali, l'ahko by bolo ich možné podviest'/zviest' a oklamat'. "

24 Trip. I/112 § 1. 
prax, ktorá umožnila ženám dosiahnuvším 24 rokov (chápaných ako dosiahnutie plnoletosti - aetas perfecta), aby požiadali o úradné zrušenie zákonného poručníctva. ${ }^{25}$ Po dosiahnutí plnoletosti mali ženy možnost' získat' plnú spôsobilost' právne konat', t. j. uzatvárat'/rušit' zmluvy, scudzovat', zálohovat' nehnutel'nosti, pričom od 16. roku sa žena pokladala za „vydaja schopnú“ a uzavretím manželstva (teda aj pred dosiahnutím veku 24 rokov) získala plnoletost' ${ }^{26}$

Novoveký intelektuálny (právnický) svet priznával žene čoraz istejšiu a výraznejšiu pozíciu v rodinnom práve (v duchu dôstojného, krest’anstvom ovplyvneného rovnoprávneho statusu), osobitne v pozícii ženy - manželky a matky. $\mathrm{V}$ súvislosti $\mathrm{s}$ hierarchiou moci dobové novoveké právne (aj morálne) normy kontinuitne stáli na patriarchálnom type rodiny, pričom obsah rodinnoprávnej normativity možno výstižne demonštrovat' na vzniku krest'anského novovekého manželstva, v ktorom sa prejavil per absolutum krest’anský univerzalizmus bez stavovských či iných rozdielov. ${ }^{27}$

Podl'a znenia Ostrihomského rituálu (záväzného v hraniciach Ostrihomskej arcidiecézy a vychádzajúceho zo záverov Tridentského koncilu) z roku 1772 môžeme v podmienkach Uhorska rekonštruovat' kánonickoprávny, formálny postup uzavretia sviatosti manželstva (sacramentum matrimonii), ktorý potvrdzuje formálne rovnoprávne postavenie oboch snúbencov a zásadu dobrovol'nosti uzatvorenia manželstva. ${ }^{28}$ Ak vychádzame $\mathrm{z}$ dogmatického základu novovekého kánonického práva, vyzdvihneme a reflektujeme uznanú definíciu manželstva podl'a domácej, uhorskej právnej náuky, prezentovanú v prvých decéniach 19. storočia v názore d’alšieho významného domáceho civilistu I. Kelemena, ktorý manželstvo ponímal ako ,spoločenstvo muža a ženy, ktoré vzniká legitímne slobodnou vôlou za účelom plodenia a výchovy detí ". ${ }^{29}$ Pri porovnaní so všeobecne

25 KELEMEN, ref. 12, I. Liber, s. 446; JUNG, Johann. Darstellung des ungarischen Privatrechtes. I. Band. Wien, 1818, s. 6.

26 JUNG, ref. 25, 8-9; A. Kővy ich považoval už po dosiahnutí 16. rokov za plnoleté a po vydaji za schopné scudzovat' nehnutel'nosti pod podmienkou, že zmluva nebola uzavretá podvodom, násilím, omylom v čase blízkom plnoletosti ženy, ked' ju bolo možné odvolat' (quuod fassionem vi, dolo, fraudem sive ante, sive post perfectam aetatem factam, intra annum a nuptii revocare valeant). In KÖVY, Alexander. Elementa iurisprudentiae Hungaricae. Cassoviae, 1807, s. 58.

27 DUDEKOVÁ - LENGYELOVÁ, ref. 6, s. 46

28 K obradu vyslúženia sviatosti manželstva v Uhorsku pozri Ostrihomský rituál, záväzný pre celé Uhorsko od jeho prijatia na synode v Ostrihome v roku 1629. In Rituale Strigoniense seu formula agendorum in administratione sacramentorum, ac caeteris ecclesiae publicis functionibus. Editio secunda, Tyrnaviae: Typis collegii academici Soc. Jesu, 1772, s. 150 a nasl.

29 „Matrimonium, quod aliter Nuptiae, Connubium, Conjugium audit, pro diversitate iurium, ac religionum variae consideratur, generatim finiri potest: Societas viri et foeminae, sobolis procreandae ac educandae causa, legitime inita. ", citované podl'a KELEMEN, ref. 22, II. Liber, s. 324; totožnú definíciu prijal SZLEMENICS, ref. 14, s. 132. Kelemen uviedol 
uznanou kánonickou definíciou podl'a uhorského katechizmu (uvádzanú aj domácim kánonistom P. Khlószom), prevzatú z Graciánovho dekrétu: ,, Manželstvo je spoločenstvo muža a ženy, tvoriace nerozlučitelne spoločný/jednotný život, posvätený právom Božským a l'udským "30 môžeme uzavriet', že uhorská novoveká právna veda ${ }^{31}$ zretel'ne artikulovala povinnost' (resp. vol'bu) dobrovol'ného a trvalého spojenia muža a ženy (antropologickú podstatu manželstva), odvodenú z Božieho práva a následne prijatého do kánonického, resp. laického práva. ${ }^{32}$

Už stredovekou cirkvou vyslovenú a kontinuitne aj novovekými krest’anskými cirkvami dôrazne požadovanú požiadavku rovnoprávnosti postavenia snúbencov (čo sa nezhodovalo s reálnym stavom pri bežnej praxi vynútených sobášov zo strany rodiny, rodičov voči dcéram) a dobrovol'nost' manželského súhlasu demonštrujeme na príklade oficiálneho právneho názoru nitrianskeho biskupa

tiež súdobú kánonickú definíciu: ,, Sacramentum laicis proprium, quo vir et mulier secundum praecepta Ecclesiae conjunguntur. “, zhodujúcu s definíciou protestantských cirkví: ,, Societas maris et feminae indissolubilis, et divinitus instituta, ad generationem prolis. "In KELEMEN, ref. 22, Liber II, s. 328. K etymológii a definícii manželstva z kánonického a historického pohl'adu pozri DUDA, Ján. Katolícke manželské právo. Spišské Podhradie: kňaž. sem. b. J. Vojtaššáka, 1996, s. 6-13. ISBN 8071420417.

30 „Matrimonium est viri et mulieris conjunctio, individuam vitae consuetudinem continens, cum Divini et humani Juris communicatione. "In Catechismus ex decreto SS. Concilii Tridentini, s. 420; KHLÓSZ, ref. 22, s. 165. Predmetná definícia ale našla svoj vzor u pohanských Rimanov, ktorí podobne ako krest’ania nazerali na manželstvo ako na: „celoživotné spoločenstvo muža a ženy, určené na základe Božskeho a l’udského práva“ (,, Nuptiae sunt coniunctio maris et feminae et consortium omnis vitae, divini et humani iuris communicatio “). In Modestinus 1 reg. D. 23, 2, 1. Slovenský preklad pozri BLAHO, Peter - VAŇKOVÁ, Jarmila. Corpus iuris civilis. Digesta. Tomus I., Žilina: Poradca podnikatel'a, 2008, s. 500. ISBN 9788089363070.

31 Kelemen (aj d’alší uhorskí civilisti) jednoznačne odvodzoval pôvod manželstva od výkladu kánonického práva a jeho antropologický náhl'ad na manželstvo prvého človeka Adama a jeho ženy Evy. Biblickú podstatu manželstva uvádzal aj Tridentský koncil (Sessio 24), doctrina de sacramento matrimonii. In Canones et decreta sacrosancti Oecumenici et generalis Concilii Tridentini sub Paulo III. Julio III. et Pio IV. Pontificibus maximis cum patrum subscriptionibus. Vindobonae, 1866, s. 147. Porovnaj tiež KELEMEN, ref. 22, II. Liber, s. 324.

32 Napokon uhorský katechizmus katolíckej viery z r. 1701 totožne s ich závermi charakterizoval manželstvo ako:

1) trvalé a legitímne životné spoločenstvo muža a ženy, ktoré

2) je viazané na posväcujúcu milost' a nárokujúce si osobitnú Božiu pomoc,

3) aby jeho konečným ciel’om bolo plodenie detí a ich vzájomná zbožná výchova,

4) tiež pokojné spolunaživanie spolu s povinnost'ou zotrvat' v láske až do konca života.

„Est legitima viri ac mulieris ad perpetuam vitae societatem copulatio, conferens gratiam sanctificatem, trahentem secum auxilia Dei specialia, ad prolem ex fine honesto suscipiendam, pie educandam, mutuamque cohabitationem pacifice, ac debito cum amore usque ad finem vitae retinendam. "In ILLYÉS, Stephanus. Catecheses doctrinae christianae seu compendiosa Christiani hominis, in rebus fidei, morum et controversiarum institutio. Tyrnaviae, 1701 , s. 360. 
Jozefa Wuruma (z roku 1835). Ten na margo manželského súhlasu zdôraznil emancipované postavenie snúbenice aj snúbenca: ${ }^{33}$ „Súhlas musí byt daný jasne, nie simulovane alebo fiktivne, ale úplne slobodne a vzájomne (recipročne), ak teda chýba tento potrebný súhlas $k$ vzniku manželstva, hoci by sa manželstvo konzumovalo telesným spojenim (carnali copulatione), neexistuje (est nullum). ... Manželstvo musí vzniknút pred Cirkvou a za účasti sobášiaceho kňaza a svedkov, pričom sa musi deklarovat' onen súhlas pred nimi, toto je predpokladom (prezumpciou) práva a z práva. "

Kánonistika, vrátane tej uhorskej, sa v celej historickej stredoveko-novovekej diskusii koncentrovala na dve hodnoty manželstva, v ktorých sa opätovne prejavilo spoločensky demonštrované ideálne rovnoprávne postavenie oboch manželov, ktorí obaja niesli rovnakú zodpovednost' za: plodenie a výchovu detí ako vlastnosti stvoritel'skej (prolis generatio et educatio) a vzájomné dobro a pomoc medzi manželmi (bonum coniugium) pri realizácii ich viery a sexuality. ${ }^{34} \mathrm{Plnenie}$ uvedených hodnôt, ktoré sa chápali aj ako manželské povinnosti, sa prejavovalo v každodennom rovnoprávnom nesení zodpovednosti za spoločný život a vlastnú sebarealizáciu, či v plnení najrozličnejších povinností, spoločenských rolí oboch manželov na verejnosti aj v súkromí rodiny. ${ }^{35}$ Napríklad uhorská náučná čítanka pre katolíkov z počiatku 19. storočia vysvetl'ovala nariadený (preskribovaný) účel manželstva nasledovne: „Prečo nas [Boh - M. L., A. Š.] samich do stawu toho powolal? Učinil to predne a nadewsecko pre poradne rozmnožení a wichovani ditek. Tento je tehdi Grunt najhlavnejši a najprednejši powinnosti stawu manželského. " ${ }^{36}$ Uhorská kánonistika v priebehu novoveku dospela

33 Názor p. biskup J. Wurum vyslovil v kontexte jednej manželskoprávnej kauzy katolíckych manželov zo začiatku 19. storočia. Bližšie bola celá kauza prezentovaná ako materiálová štúdia ŠVECOVÁ, Adriana. Inštitút manželstva v novoveku na pozadí sporu o rozluku Jána Dubničku versus Alžbety Magyaryovej. In Historický časopis, 2016, roč. 64, č. 2, s. 231-248. ISSN 0018-2575.

34 Uhorský katechizmus k tomu ešte doplnil: ,aby manželia nepocitovali ostrost' telesnej žiadostivosti, a aby ich duše jej nemuseli príliš vzdorovat', môžu (manželstvo) použit' ako prostriedok proti prílišnej žiadostivosti “. Podl'a ILLYÉS, ref. 32, s. 365. Na zachovanie l'udskej dôstojnosti pri sexuálnom akte apeluje I. Frank. In FRANK, Ignatius. Principia iuris civilis Hungarici. Tomus I. Pestini, 1829, s. 118.

35 Oba ciele kánonistika zároveň uznala za vzájomné manželské povinnosti. Potridentská náuka (z ktorej čerpala aj uhorská civilistika) sa vyjadrila k uvedeným ciel'om plodenia detí a vzájomného dobra a pomoci manželov a určila ich vzájomnú hierarchiu, pričom prvý ciel' redefinovala ako primárny a druhý ako sekundárny.Všetky hodnoty zároveň synonymicky tvorili ciele manželstva (finis matrimonii), t. j. k akým dobrám/hodnotám vlastne manželstvo malo smerovat' a aký bol jeho účel. Pozri aj súdobú katolícku čítanku HABEL, Franciscus. Učeni mudrosti krest'anskej skrz které chudobni (neskazeného) srdca ewanjelizowani to jest, IV. stránka: O swatích Swátostách. Trnava, 1802. s. 182-194.

Uvedený významový postulát ciel’ov sa nezmenil ani v prvom kodifikovanom CIC/1917, kán. 
k nasledujúcim znakom krest’anského manželstva: „, výhradného rovnoprávneho zväzku muža a ženy, jeho pevnosti, stálosti a hlbokého spojenia oboch manželov $v$ doživotnom spoločenstve s bezpodmienečným prijatím hlavného ciel'a plodenia deti “ ${ }^{37}$ Uvedený model manželstva sa bez zásadných výhrad všeobecne akceptoval v čase neskorého novoveku, ${ }^{38}$ pričom postavenie ženy v rámci rodiny prechádzalo už počas stáročného stredoveko-novovekého vývoja pomalým prerodom nesmierne významným $\mathrm{z}$ hl'adiska práva a vôbec postavenia ženy $\mathrm{v}$ spoločnosti. Žena nadobudla v súkromnom živote rodiny spoločnost'ou všeobecne akceptovanú pozíciu, a to pozíciu ženy ako matky a rodičky synov v záujme zachovania rodiny a rodu a pozíciu ženy ako hospodárky či správkyne kl'účov ${ }^{39}$ a majetku spravidla získaného manželom. ${ }^{40}$ Uvedený status v istej miere obmedzovala nerovná pozícia vo vzt’ahu $\mathrm{k}$ výchove detí (s výnimkou k malým det’om).

Do istej miery zaujímavejšia bola pozícia ženy v oblasti vecného práva - a to v práve na majetok, či už na majetok rodinný (rodový), alebo na majetok individuálny (vlastný). ${ }^{41}$ Majetkovoprávny status ženy bol v oblasti šlachtického práva vymedzený tak, že žena sama spravovala vlastný majetok, ktorý si do

1013 § 1. V súčasnom CIC/1983 už uvedená hierarchia nie je vôbec prítomná, pretože živá diskusia počas 20. storočia dospela k rovnocennosti oboch ciel'ov. In KAŠNÝ, Jiří. Manželství v západní tradici. Soubor kanonických studií. České Budějovice: Jihočeská univerzita, 2006, s. 32-33. ISBN 9788070409213.

37 Spoločenstvo muža a ženy zdôraznil d’alší významný domáci civilista I. Frank, ktorý akcentoval jeho súkromný charakter (domestica vitae societas). In FRANK, ref. 34, s. 118.

38 V tejto súvislosti je zaujímavá stabilnost' uvedeného manželského ideálu ešte i na konci 19. storočia, ked' dochádza k prijatiu prvej laickej právnej normy v podobe zákonného článku 31/1894 o manželskom práve. Ten zakotvil svetský charakter manželstva a obligatórny civilný sobáš, avšak idealizovaný model sviatostného manželstva sa interne psychologizoval podl’a krest’anského starovekého kánonu do stále pretrvávajúceho sviatostného patriarchálneho manželstva aj so zabehnutými stereotypmi manžela a manželky.

39 V stredovekej symbolike (slovanské, germánske právo) boli kl’úče symbolom postavenia ženy v manželstve a rodine. LUBY, Štefan. Klúčna moc manželky. In Právny obzor, 1944, roč. 27, č. 3 a 4 , s. 1 .

40 KLAPISCH-ZUBEROVÁ, Christiane. Žena a rodina. In Le GOFF, Jacques (ed.). Středověký člověk a jeho svět. Praha: Vyšehrad, spol. s r. o., 2003, s. 261. ISBN 9788070216828; BŮŽEK, Václav - HRDLIČKA, Josef - KRÁL, Pavel - VYBÍRAL, Zdeněk. Věk urozených. Šlechta v českých zemích na prahu novověku. Praha: Paseka, 2002, s. 307. ISBN 8071854174. K meštianskej barokovej spoločnosti, kde sa vyzdvihoval ideál cnosti, zbožnosti, rozvážnosti a zodpovednosti a kde sa povýšil vzor nukleárnej rodiny na ústredné miesto v spoločenských vzt’ahoch pozri aj VILLARI, Rosario. Barokní člověk a jeho svět. Praha: Vyšehrad, 2004, s. 313. ISBN 8070216832.

41 Konklúzie k majetkovému postaveniu manželov vychádzajú z monografie LACLAVÍKOVÁ, Miriam. Formovanie úpravy majetkových vztahov medzi manželmi: (od vzniku uhorského štátu do prvej československej kodifikácie rodinného práva). Bratislava: Veda Vydavatel'stvo Slovenskej akadémie vied, 2010. ISBN 9788022411424. 
manželstva priniesla; na druhej strane však právo kompenzovalo neexistenciu jej práv k rodovému (donačnému) majetku manžela vytvorením konceptu osobitných práv žien (z nich možno osobitne spomenút' vdovské právo (ius vidualle), vdovské dedenie (successio vidualis) a obvenenie (dos legalis). V oblasti poddanského a mestského práva, kde vznikalo spoločenstvo majetku nadobudnutého počas manželstva (koakvizícia), vystupovala žena ako spoluvlastníčka spoločného manželského majetku (k zväčšeniu ktorého prispievala vlastnou prácou) so všetkými z toho vyplývajúcimi dôsledkami. V procese emancipácie žien je totiž potrebné zohl'adnit' aj otázku bývalého privilegovaného alebo neprivilegovaného postavenia, ${ }^{42}$ ktoré malo priamy vplyv na postavenie ženy $\mathrm{v}$ oblasti rodinného, vecného a dedičského práva.

Kompenzáciu ,za to, že $k$ nemovitostem neměly ženské zpravidla žádného spoluvlastnického práva “, bol stredovekou právnou vedou vytvorený a všeobecne akceptovaný katalóg osobitných práv žien, ktorým sa im ,zabezpečovala slušná existence jednak, dokud se neprovdaly a žily na statcích otcovských, jednak když se provdaly a pak ovdověly, a žily tedy na statcích mužových ". ${ }^{43}$ Osobitné práva žien vytvárali špecifický uhorský katalóg práv vecnoprávnej, dedičskej, osobnoprávnej povahy, ${ }^{44}$ a medzi ne patrili:

1. právo dievčenskej štvrtiny (quarta puellaris seu filialis, quartalitium);

2. vlasové právo (jus capillare);

3. právo na obvenenie (dos, dotalitium);

4. právo na veno alebo prínos (allatura);

5. právo na snubný dar, resp. svadobný dar (paraphernum, res paraphernales);

6. právo manželky na polovicu majetku spolunadobudnutého s manželom počas trvania manželstva (coaquisitio conjugalis) - vyskytujúce sa len vo vrstve poddaných a mešt’anov, resp. výnimočne cestou manželskej zmluvy aj u šlachticov v období neskorého novoveku. ${ }^{45}$

42 Novoveké právo vychádzalo zo stredovekých základov s imanentnou črtou právneho partikularizmu, ktorého podstatou bolo rozčlenenie právneho poriadku na partikulárne subsystémy, t. j. osobitný právny subsystém pre šlachtu, osobitný pre poddaných a osobitný pre meštanov. Postavenie ústavného práva, t. j. základných zásad právneho poriadku spoločnosti a štátu malo krajinské šl'achtické právo, ktorého podstata bola zhrnutá v Zlatej bule Ondreja II. a v jej konfirmáciách (verejnoprávna rovina) a v diele Opus Tripartitum (súkromnoprávna rovina).

43 KADLEC, Karel. Verböczyovo Tripartitum a soukromé právo uherské a chorvatské šlechty $v$ něm obsažené. Praha: Nákladem České Akademie císaře Františka Jozefa pro vědy, slovesnost a umění, 1902, s. 246.

44 KADLEC, ref. 43, s. 246-247.

45 O koakvizícii viac v II. kapitole, ked' sa tento inštitút rozšíril na všetky skupiny obyvatel'stva, v mestskej aj vidieckej societe. O nej tiež pojednáva a definuje ju KELEMEN, ref. 22, s. 226-231. 
Uvedené osobitné práva žien (ako práv rodovo identifikovaných) doplńnali: vdovské právo (ius vidualle) ${ }^{46}$ a vdovské dedenie (successio vidualis), ${ }^{47}$ pričom treba spomenút', že podobná zvýhodňujúca či rovnocenná právna úprava pre vdovcov sa v Uhorsku vôbec nevyvinula. ${ }^{48}$ Vdove patrilo okrem nižšie uvedených vdovských dedičských nárokov osobitné vdovské právo (ius viduale), ktorého ochranu položili už zákony Štefana I. ${ }^{49}$ Vdovské právo sa vytvorilo na konštrukcii užívacieho práva (usus fructus) na celú pozostalost' manžela za predpokladu, že vdova zotrvala vo vdovskom stave, , ktorú dovtedy, pokial' preživa svoje vdovstvo pod menom a titulom svojho zomrelého manžela a neuzavrie nové manželstvo, nemožno ani napriek vyplateniu obvenenia vylúčit' z majetkov, pozemkových práv, domov patriacich jej manželovi “50 a tiež za predpokladu, že uzavrela pôvodné platné manželstvo. ${ }^{51}$ Uvedená vyživovacia povinnost' (označovaná ako vitatium alebo Unterhalt ${ }^{52}$ ) sa odvodila z pôvodnej manželovej povinnosti alimentovat' počas manželstva manželku a táto prešla po jeho smrti na manželovu pozostalost', resp. dedičov tejto pozostalosti. ${ }^{53}$ Podstatou vdovského práva ${ }^{54}$ bolo zabezpečenie dôstojného života primeraného stavu vdovy po smrti manžela. ${ }^{55}$ Vdova podl'a neho mala právo na užívanie a požívanie majetkov zom-

46 Základná právna úprava vdovského práva in Trip. I/29, I/30, I/67, I/98 a I/134.

47 Základná právna úprava vdovského dedenia in Trip. I/99. In KERN, Teodor. Die gesetzliche Erbfolge in Ungarn. Wien: Alfred Hölder, K.u K. Hof- und Universitäts-Buchhändler, 1897, s. 55 a n..

48 KÖVY, Summarium, ref. 22, s. 81.

49 „Ak nejaká žena ovdovie a zostane so svojimi synmi a dcérami a zloži slub, že ich vychová a zostane s nimi, pokial’ žije, nech si uživa od nás dané právo, aby toto mohla urobit'... Ak však zmení svoj stav, a znova sa chce vydat' a siroty chce opustit', nech z majetku sirôt nič nedostane, iba svoje šaty. “ Citované podl'a LACLAVÍKOVÁ, Miriam - ŠVECOVÁ, Adriana. Pramene práva na územi Slovenska I. Od najstaršich čias do roku 1790. Trnava: Typi Tyrnaviensis Universitatis, 2007, s. 66. ISBN 9788080821531.

50 Trip. $\mathrm{I} / 98 \S 1$.

51 Trip. I/106.

52 ŠVECOVÁ, Adriana. Trnavské meštianske závety (1700 - 1871). I. zv. Trnava: Typi Tyrnaviensis, 2014, s. 120. ISBN 9788080827007.

53 KERN, ref. 47, 1897, s. 55 n., tiež GZOVSKÝ, Vladimír. Privátne testamenty podl'a práva platného na Slovensku a v Podkarpatskej Rusi. Rukovät' k ich sostaveniu, vzory, nástin dedičského práva. Prešov: tlačou a nákladom Sv. Mikuláša, 1925, s. 64 n.

54 „Beneficium viduae competens, ex juribus possessionariis haereditariis, et ipsam jure proprietatis non concernentibus, congruentem habitationem, et sustentationem, ac, si demo nubere velit, etiam emeritationem, percipiendi. " FRANK, ref. 34 s. 295; KELEMEN, ref. 22, II. Liber, s. 205.

55 „Účelom vdovského práva je, aby vdove, dokedy žije a nosí meno zostavitelovo, bola poskytnutá z celej pozostalosti slušná výživa, primeraná spoločenským a majetkovým pomerom zostavitel'ovým, a bývanie v dome manželovom. Povinnost' manžela vydržiavat' manželku vlastne prejde na jeho pozostalost." "GZOVSKÝ, ref. 53, s. 64. 
retého manžela, ${ }^{56}$ zahŕňajúce stavu zodpovedajúce bývanie a zaopatrenie (obmedzené často po výšku obvenenia), a to až do času jej smrti, prípadne nového vydaja, ked' mala právo aj na poskytnutie primeranej výbavy. ${ }^{57}$ Vdova zároveň bola povinná nepoškodzovat' majetok patriaci už zákonným dedičom zomretého manžela ${ }^{58}$ a zachovat' pre nich jeho podstatu. Uvedený inštitút platil pôvodne len v šlachtickom práve, no postupne právnou obyčajou sa rozšírila jeho platnost' aj pre neprivilegované vrstvy. ${ }^{59}$ Do vydania zák. čl. XI/1687 šl'achtická vdova neparticipovala vo všeobecnosti na dedičstve (najmä na nadobudnutom majetku) po manželovi, ale jej preferenčné dedičské nároky vymedzilo Trip. a naň nadväzujúce zákonodarstvo nasledovným spôsobom: vdova po šlachticovi (alebo neskôr aj po tzv. honoraciorovi - nešl'achticovi, živiacemu sa duševnou prácou, akými boli napr. lekári, advokáti, univerzitní profesori a pod. ${ }^{60}$ dedila na základe osobitného vdovského dedenia manželov snubný prsteň, manželov slávnostný oblek, konský záprah a koč, polovicu žrebčína (ak mal menej ako 50 kusov koní) a popri potomkoch jeden detský podiel z nadobudnutého (ne)hnutel'ného majetku manžela. ${ }^{61}$ Po vydaní reštrikcie zák. čl. XI/168762 šl’achtická vdova ${ }^{63}$ dedila

56 Spočiatku mala vdova užívacie a požívacie právo k celej pozostalosti manžela. Od účinnosti zák. čl. 11/1687 sa toto právo vdovy vzt’ahovalo len na majetok aviticitný (ak totiž nebolo potomkov, vdova dedila všetok nadobudnutý majetok).

57 JUNG, ref. 25, II. Band, s. 77.

58 FRANK, ref. 34, s. 295.

59 Vdovské právo a zabezpečenie tzv. vdovskej výživy u poddaných upravil zák. čl. 8/1840 o dedičskom práve poddaných v ustanoveniach $\S 16-\S 18$. Pozri bližšie REBRO, Karol. Dedičské právo k urbárskej usadlosti od 18. storočia do buržoáznej revolúcie na Slovensku. In Právněhistorické studie, 1964, roč. 10, s. 74.

60 Otázka chápania vrstvy honoraciorov ako novej spoločenskej elity nastávajúceho veku novodobých a (post)-moderných dejín nebola v súdnej praxi jednoznačne riešená. Spočiatku sa za honoraciorov považovali všetci nešl'achtici, ktorí sa neživili manuálnou prácou (t. j. aj učitelia na l’udových školách, poštoví úradníci a i.). Postupne sa však okruh honoraciorov zužoval s prihliadnutím na druh a charakter vzdelania, úradného postavenia a druhu vykonávaného povolania, a za honoraciorov sa považovali len osoby s vysokoškolským vzdelaním. Úradníci bez vysokoškolského vzdelania sa za honoraciorov považovali len výnimočne - ak zastávali významnú pracovnú pozíciu.

61 ŠVECOVÁ, Adriana. Dedičské právo šl'achty v Uhorsku s prihliadnutím na právne pomery neskorého novoveku a slobodného král'ovského mesta Trnavy. In KOVAČKA, Miloš - AUGUSTÍNOVÁ, Eva - MAČUHA, Maroš (eds.). Zemianstvo na Slovensku. Zborník prác z interdisciplinárnej konferencie, ktorá sa konala 8. - 10. júna 2009 v Martine. Martin: Slovenská národná knižnica, 2009, Zv. I., s. 214-215. ISBN 9788089301508. Dostupné aj na: http:// www.snk.sk/swift_data/source/NBU/Zborniky/Zemianstvo_1/199.pdf

62 Znenie predmetného zákonného článku explicitne v $§ 1$ len doplnilo (rozšírilo) stále platnú úpravu Tripartita. Zaradenie vzájomného dedenia manželov medzi zákonný dedičský titul pripomenul podobne $\S 4$ zák. čl. XXVI/1715.

63 Zákon však všeobecne formuloval vzájomné dedičské nároky manželov, nielen vdovy a po 
celý nadobudnutý nehnutel’ný majetok (označovaný Imrichom Kelemenom aj ako koakvizícia - massa coacquisita) s odôvodnením, že sa nadobudol zväčša kúpou za peniaze, ktoré sa vždy chápali ako hnutel'nost' a tie simile od počiatkov patrili pozostalej manželke. ${ }^{64} \mathrm{Na}$ aviticitnom (zdedenom) majetku mala len zákonné vdovské požívacie právo, nie dedičský nárok. ${ }^{65} \mathrm{~V}$ otázke vdovského dedenia (successio vidualis) sa v meštianskom a podobne aj v poddanskom práve rozvinulo dedičské právo vdovy minimálne na jeden dedičský podiel spolu s legitímnymi potomkami zosnulého manžela a tiež užívacie právo (ius viduale) na pozostalost' zosnulého manžela. ${ }^{66}$

Právnu úpravu majetkových vzt'ahov medzi manželmi možno zasadit' do európskeho vývoja, ktorý poznal dva modely: prvý vychádzal z oddelenia majetku oboch manželov (dotálny systém) - v ktorom obaja manželia nadobúdali osobitný majetok a pre druhý bolo signifikantné vytvorenie konštrukcie kolektívneho, spoločne nadobudnutého majetku (koakvizičný systém). ${ }^{67}$ Toto členenie súčasne odkrývalo stavovský charakter uhorského kombinovaného manželského majetkového práva, kde sa uplatnili oba modely (systémy), nakol'ko dotálny bol charakteristický pre privilegované vrstvy a koakvizičný systém pre vrstvy neprivilegované (o nich nižšie pri výklade koakvizície).

Vzt’ahy medzi šlachtickými manželmi (aj v manželstvách tzv. honoraciorov) sa riadili režimom oddelených majetkov manželov. Podstatou tohto usporiadania majetkových vzt’ahov bolo vylúčenie skutočnosti spoločne nadobúdat' majetok obomi manželmi od doby uzavretia manželstva až do jeho zániku. V šl'achtickom práve totiž manželka a priori nemusela prispievat' k zväčšovaniu rodinného a počas manželstva nadobudnutého majetku, ked’že právo tu vychádzalo z domnienky, že manžel je jediným nadobúdatel'om (principalis acquisitor). V praktickej rovine dotálny model znamenal, že tak muž, ako aj žena mali právo disponovat' so svojím vlastným (výlučným) majetkom aj počas trvania manželstva samostatne. Ženy však zväčša vystupovali ako samostatné nadobúdatel'ky majetku, a nie spolunadobúdatel'ky majetku (,,dotalistae vero intelligi debeant simplices, et non coaquisitrices, seu proprietariae"). ${ }^{68}$ Nadobúdali predovšet-

prvýkrát priznal pozostalému manželovi nárok na manželkin majetok alebo podiel z neho.

64 Zák. čl. XI/1687: „, marito absque haeredibus et testamento ex hac luce decedente, universa bona per ipsum titulo pignoris inventa, et parta, prouti et res mobiles ... in uxorem ispius superstitem devolvantur".

65 LACLAVÍKOVÁ, ref. 41, s. 45.

66 Uvedené dokumentuje aj zbierka taverníckeho práva v III. knihe, čl. 1 a 6. In MERTANOVÁ, Štefánia. Ius tavernicale. Príloha II. Bratislava: Veda, 1985, s. 201-206. ISBN 7103785.

67 ŠORL, Róbert. Manželské majetkové právo na Slovensku a ABGB v rokoch 1848 - 1949. In SCHELLE, Karel (ed.). Sborník z medzinárodni vědecké konference Vývoj právních kodifikací. Brno: Masarykova univerzita, 2004, s. 166. ISBN 8021036109.

68 Zák. čl. LXVII/1622 § 3. V oblasti poddanského a mestského práva bola žena v zásade takmer 
kým osobitné majetkové práva (medzi nimi okrem obvenenia a vdovského práva aj veno a parafernálny majetok), k čomu sa pripojilo od prijatia zák. čl. XI/1687 vzájomné dedenie manželov, a všetky zmienené inštitúty našli svoje uplatnenie (resp. plnenie obvykle formou finančného vyrovnania) zásadne až pri, resp. po zániku manželstva.

Zásadným inštitútom zaopatrenia manželky - vdovy pri zániku manželstva smrt'ou manžela sa v systéme oddelených majetkov šl'achtických manželov stal inštitút obvenenia (obveno, venné).$^{69}$ Obvenenie $^{70}$ (dos, dotalitium, hitbér) predstavovalo v najširšom význame majetok patriaci legitímnej manželke - vdove z majetku manžela. ${ }^{71}$ Tento inštitút bol opätovne upravený v dvoch formách: zákonného alebo zmluvného obvenenia vo viacerých článkoch Tripartita, ${ }^{72}$ pričom sa označovalo ako ,,dos “ alebo ,,dotalitium “.

Vymedzenie alebo definíciu obvenenia nachádzame v Trip. I/čl. 93, podl’a ktorého bolo obvenenie odmenou legitímnej manželky (,,merces foeminarum legitime conjugatarum " $)^{73} \mathrm{z}$ majetku a majetkových práv manžela (,, de bonis, et juribus possessionariis maritorum ") za stratu panenstva a plnenie manželských povinností (,,propter eius deflorationem, et concubitum “). ${ }^{74}$ Nárok na zákonné obvenenie (na rozdiel od zmluvného) vznikal konzumáciou manželstva (conssumatio matrimonii), avšak k jeho vyplácaniu alebo vydaniu dochádzalo až po zániku manželstva (čo v minulosti znamenalo prakticky zánik manželstva najčastejšie smrt'ou manžela) pre ul'ahčenie postavenia vdovy. ${ }^{75}$ Výška zákonného

vždy spolunadobúdatel'kou majetku nadobudnutého za trvania manželstva.

69 V slovenskej historiografii označované aj ako venné, venný majetok.

70 HUDÁČEK, Pavol. The legal position of widows in medieval Hungary up to 1222 and the question of dower. In Historický časopis, 2014, vol. 62, supplement, s. 4, ISSN 0018-2575; LACLAVÍKOVÁ, ref. 41, s. 130.

71 „Dos vel Dotalitium est certa summa foeminis legitime copulatis vel secundum legem, vel secundum contractum ex Bonis maritalibus deponi solita. "KÖVY, ref. 26, s. 202-203.

72 Konkrétne ide o články: I. čast' (čl. 27 § 2, čl. 28, čl. 29 § 4, čl. 30 § 7, čl. 59 § 2, čl. 67 § 2, čl. 78 §, čl. 88, čl. 93, čl. 94 § 3, čl. 95, čl. 96, čl. 97, čl. 98 § 1-3, čl. 100, čl. 101 § 3, čl. $102 \S$ 2, čl. 103, čl. 104, čl. 105, čl. 106, čl. 109, čl. 111 § 7, čl. 129 § 1, čl. 134 § 3-4), II. čast' (čl.

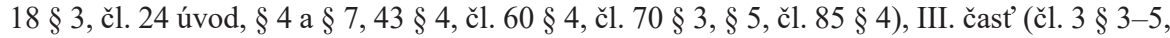
$\S 9$, čl. 7 § 3,5).

73 „Dotem seu dotalitium competere solis mulieribus tantum legitime conjugatis; non ideo concubinis; neque uxoribus incestuosis. "HUSZTY, Stephanus. Iurisprudentia practica seu Commetarius novus in ius Hungaricum. Liber secundus, Agriae, 1778, s. 243.

74 Trip. I/čl. 93 Úvod ,... dotalitium vel solummodo dotem dicimus: Et est quae uxori propter eius deflorationem, et concubitum, de bonis mariti datur". Trip. I/čl. $93 \S 2, \ldots$ dotalitium est merces foeminarum legitime conjugatarum, ob debitum matrimonii, de bonis, et juribus possessionariis maritorum, juxta status illorum exigentiam dari consueta ".

75 ,dos debebatur sub conditione mortis mariti“, preto pred jeho smrt'ou manželka a ani jej dedičia obvenenie nemohli žiadat'. KELEMEN, ref. 22, II. Liber, s. 223. Porovnaj aj JUNG, ref. 25 , s. 82. 
obvenenia ${ }^{76}$ závisela od spoločenského stavu manžela a vel'kosti jeho majetku, ${ }^{77}$ pričom Werbőczy v Trip. takmer vždy uvádza súčasne pojmy (donačný) majetok a pozemkové práva. ${ }^{78} \mathrm{U}$ manželky baróna (baro regni) bolo obvenenie stanovené ${ }^{79}$ sumou 100 hrivien (t. j. 400 zlatých $)^{80}$ a u manželky magnáta a popredného šlachtica sumou 50 hrivien (t. j. 200 zlatých). ${ }^{81}$ Okrem toho však dôležitým faktorom výšky obvenenia bola skutočnost' počtu ženou uzavretých manželstiev, ked’že sa jeho výška uzavretím každého d'alšieho manželstva znižovala o polovicu, t. j. pri druhom manželstve manželke patrila len polovica Tripartitom stanoveného obvenenia, pri tret'om už len štvrtina a pri štvrtom osmina sumy obvenenia. ${ }^{82} \mathrm{~K}$ plneniu obvenenia najčastejšie dochádzalo troma spôsobmi. ${ }^{83}$ Vývojovo najstaršími boli prevod vlastníctva, ${ }^{84}$ dedičnej držby či dočasného užívania ur-

76 Tripartitum zohl’adnilo aj osobitné obyčaje Slavónie a Sedmohradska týkajúce sa výšky a výplaty obvenenia. Obvenenie vdovy (s výnimkou vdovy baróna, ktoré bolo rovnaké ako v Uhorsku) bolo v Slavónii 100 zlatých a v Sedmohradsku 66 zlatých, prípadne u menej majetných šlachticov primerane nižšie (Trip. III/3 § 3, § 4 a § 5). Osobitost’ou výplaty obvenenia bolo, že dve tretiny obvenenia sa zvyčajne vyplácali v peniazoch a jedna tretina v hnutel’ných, l'ahko speňažitel'ných veciach (Trip. III/3 § 9).

77 Trip. I/93 § 3. V zmysle ustanovenia Trip. I/čl. $133 \S 18$ bola obývaná poddanská usadlost' ocenená na hodnotu 1 hrivny (t. j. 4 zl.). Obvenenie manželky bohatšieho šl’achtica (magnáta a popredného šl'achtica), ktorý mal 50 a viac obývaných poddanských usadlostí, bolo teda Trip. stanovené na pomerne značnú sumu - 50 hrivien, t. j. 200 zl.. Vo všeobecnosti mala vdova získat' takú sumu obvenenia (počítanú v hrivnách), kol'ko obývaných poddanských usadlostí vlastnil jej manžel. Pozri aj KADLEC, ref. 43, s. 255 a s. 126.

78 Trip. I/čl. $96 \S 2$.

79 Trip. I/ $93 \S 4$.

80 Na porovnanie suma 100 hrivien (400 zlatých) predstavovala aj cenu kamenného hradu alebo kláštora s pohrebiskom patrónov a iných významných šl'achticov. Trip. I/133 $§ 6$ a $§ 7$ (tzv. večná cena).

81 Na porovnanie suma 50 hrivien (200 zlatých) predstavovala aj cenu kostola s dvoma kupolami postaveného na spôsob kláštora (kostol s dvoma vežami alebo kupolami, ktorý nebol kláštorom, bol ocenený len na 25 hrivien a katedrálny kostol s jednou vežou a pohrebiskom na 15 mariek). Trip. I/133 $\S 8, \S 9$ a $§ 10$ (tzv. večná cena).

82 Trip. I/čl. 96: „Item advertendum; quod qualibet foeminarum, a primo marito (ratione floridae virginitatis, in qua nuptui tradita fuit) integram dotem: a secundo vero, post deflorationem scilicet nubendo; mediam duntaxat dotem: a tertio quartam partem; a quarto, octavam solum partem dotis habet. “ Trip. I/čl. $96 \S 1$,Si que autem etiam quinto, vel sexto marito nupserit; dos sua in tantum minuetur, ut admodum exigua sit futura. “

83 LUBY, Štefan. Liptovský a turčiansky register z roku 1391. (Príspevok k otázke donačného systému na Slovensku). Bratislava: Nákladom Vydavatel’ovým. V Komisii J. Otto, Filiálka v Bratislave, 1932, s. 51; ŠVECOVÁ, Adriana - LACLAVÍKOVÁ, Miriam. Osobitné práva žien na podklade listín hodnoverných miest vrcholného stredoveku v Uhorsku. In BLAHO, Peter (ed.). Acta Universitatis Tyrnaviensis - Iuridica. Trnava: Typi Universitatis Tyrnaviensis, 2009, roč. 6, s. 335-337. ISBN 9788080823283.

84 Listina Nitrianskej kapituly z roku 1242 opisovala plnenie obvenenia v konkrétnej výške (,pro quinquaginta marcis racione dotis") prevodom vlastníctva k dedičnej nehnutel'nos- 
čitej nehnutel'nej veci ${ }^{85}$ a uspokojenie pohl'adávky z obvenenia prevodom vlastníctva $\mathrm{k}$ určitým druhom hnutel'ných vecí $\mathrm{v}$ stredovekom práve považovaných za peňažný ekvivalent. ${ }^{86}$ Podla Trip. plnenie obvenenia sa malo zásadne uskutočnit' v peniazoch ${ }^{87}$, prípadne aj v hnutel’ných veciach, ktoré boli l'ahko likvidné a chápali sa ako ekvivalent peňazí (zväčša dobytok), pričom Trip. I/čl. $95 \S 1$ vylúčilo isté veci ako nespôsobilé na výplatu obvenenia (napr. zaplátané šaty, chromý dobytok, zbrane). Okrem zákonného (stanoveného v Trip.) obvenenia sa v Uhorsku uplatňovalo aj tzv. zmluvné obvenenie (dos scripta vel contractualis, irott hitbér), a to nielen v systéme krajinského šl'achtického práva, ale aj $\mathrm{v}$ iných partikulárnych právnych systémoch (napr. v mestskom). Zmluvné obvenenie vznikalo na základe platnej zmluvy (najčastejšie formou predmanželskej alebo svadobnej zmluvy), resp. sl’ubu manžela, prípadne na základe závetu, ${ }^{88}$ ktorými sa manžel zaviazal manželke poskytnút' určitú, spravidla vyššiu sumu v porovnaní s výškou zákonného obvenenia. ${ }^{89}$ Obvenenie popri vdovskom práve vytváralo právnu možnost' dôstojného života ženy - vdovy vo sfére krajinského šl'achtického práva aj s prihliadnutím na ich značný majetkový význam.

Veno (allatura uxorea) a prínos (pharafernum) poznali privilegované aj neprivilegované stavy. Za veno sa chápal majetok, ktorý v čase uzavretia manžel-

ti pre vdovu po Pousovi, trenčianskom jobagiónovi, ktorú predstavovala Pousova zdedená osada Luborča, k čomu však došlo so súhlasom všetkých príbuzných manžela (cognatorum). MARSINA, Richard (ed.). Codex diplomaticus et epistolaris Slovaciae. Tomus II. Inde ab a. MCCXXXV usque ad a. MCCLX. Bratislava: Obzor, 1987, s. 77, č. 117.

85 Podl’a listiny Bratislavskej kapituly z 1. júna 1309 synovia Juraja z osady Wlky prenechali do doživotnej držby majetok Wlky vdove Bybur a jej synovi. Tento majetok sa však mal po ich smrti vrátit' synom Juraja. Pozri SEDLÁK, Vincent (ed.). Regesta diplomatica nec non epistolaria Slovaciae. Tomus I. inde ab. a. MCCCI ad a. MCCCXIV. Bratislava: VEDA, Vydavatel'stvo Slovenskej akadémie vied, 1980, s. 292, č. 656.

86 Listina Šahanského konventu z roku 1322 uvádzala dva voly v hodnote dvoch hrivien a víno za osem hrivien. SEDLÁK, Vincent. (ed.). Regesta diplomatica nec non epistolaria Slovaciae. Tomus II. (RDS1 II.), s. 379, č. 871. Plnenie obvenenia predmetmi luxusnej potreby sa uvádzalo v listine Nitrianskej kapituly z roku 1321, ktorá zrejme postihla aj prínos a čast' vdovského dedenia. Plnenie pre vdovu Alžbetu tak obsiahlo predmety, ako jeden zlatý kríž v hodnote dvanástich hrivien, celú výzbroj po svojom manželovi Gabrielovi ocenenú na šest' hrivien, dvoch volov, dvadsat'tri vybraných oviec, šestnást' starých a dobrých obrusov alebo uterákov za dve hrivny, d’alej striebornú nádobu (džbán) v hodnote dvoch hrivien, taktiež koňa v hodnote desiatich hrivien a opasok ocenený na pät' a pol hrivny. SEDLÁK, RDSl II., s. 311, č. 694.

87 Trip. I/95, prologus: „partim pecuniis numeratis, partim vero rebus mobilibus, et venalibus “.

88 KÖVY, ref. 22, s. 79-80; TIMON, Ákos. Ungarische Verfassungs und Rechtsgeschichte mit bezug auf die Rechtsentwicklung der westlichen Staaten. Berlín, 1904 s. 354.

89 HERCZEGH, Mihály. Magyar családi és öröklési jog a vonatkozó újabb törvények-, felsőbb rendeletek- és egy döntvényfüggelékkel, mely a m. kir. Curiának, úgyis mint hétszemélyes, úgyis mint legeőbb itélöszéknek elvi határozatait tartalmazza. Budapest 1885, s. 39. 
stva dostávala manželka od rodiny alebo od tretej osoby pre l'ahšie znášanie spoločného manželského života a potrieb rodiny. ${ }^{90} \mathrm{~V}$ prípade prínosu ho novoveká veda zaradila medzi podinštitút vena, rozšíriac okruh osôb, ktoré ho dávali, aj čo do časového hl'adiska jeho plnenia: išlo o hnutel'ný majetok, ktorý manželka dostávala $\mathrm{z}$ titulu manželstva $\mathrm{v}$ čase sobáša aj po ňom od kohokol'vek, prinášajúc ho do manželstva najmä pre svoju osobnú potrebu a potreby domácnosti. ${ }^{91}$ V mestskom prostredí sa za veno aj prínos najčastejšie považovali typické hnutel'né veci slúžiace vybaveniu domácnosti (napr. postel'ná bielizeň alebo kuchynský riad). ${ }^{92}$ Časovým momentom odovzdania (plnenia) vena aj prínosu bol okamih vydaja manželky (uzavretím manželstva) a jej príchodu do domu manžela, a preto sa prínos stotožňoval so snubným či svadobným darom alebo výbavou. ${ }^{93}$

Realizácia ženy v danej dobe bola, prirodzene, rodinným okruhom uzavretá, len v minimálnej miere sa dialo jej širšie spoločenské uplatnenie aj navonok. Medzi také výnimočné a právom dovolené prejavy patrila možnost' vdovy matky byt' zákonnou poručníčkou svojich detí; možnost' ženy spravovat' svoj vlastný výlučný majetok (pochádzajúci z vena, obvenenia (dos) či parafernálií), prípadne v možnosti vdovy užívat' z titulu vdovského práva majetky zomrelého manžela. Vo verejnoprávnej rovine sa realizácia žien nepredpokladala a ani sa zvlášt' v právnej vede nepertraktovala. Vo svojej podstate pozícia ženy sa začala vyhodnocovat', otvárat' a predostierat' spoločnosti ako problém až po nástupe osvietenstva $\mathrm{v}$ súvise $\mathrm{s}$ presadzovaním zásady rovnosti.

Právnu pozíciu ženy ako východisko následného emancipačného snaženia po roku 1848/49 teda možno determinujúco vnímat' v kontrapozícii so stredovekou pozíciou práv mužov ako plnoprávnych vlastníkov majetku a zákonných dedičov (reštrikcia práv žien) a s prihliadnutím na isté ochranárstvo a protekcionizmus, ktorý vyústil do zakotvenia osobitných a vyššie definovaných tzv. ženských práv.

\section{Status ženy a jej právna a spoločenská emancipácia v období 19. a začiat- ku 20. storočia}

Pozícia ženy, pôvodne výrazne uzavretá do rodiny a súkromia, sa začala na prelome rokov 1848/49 zásadne menit', pričom, ako sme si už v úvode pripomenu-

90 Jeho extenzívny výklad viazaný na rímske veno (,,cum dote romana in eo congruit, quod marito serviat ad facilius ferenda matrimonii onera") vyložil KELEMEN, ref. 22, II. Liber, s. 233 a nasl.

91 „,mobilia ... illla enim, quae mulieri per sponsum, alterutrius parentes, cognatos, aut quemvis alium, tempore solennitatis nuptiarum, desponsationis, vel subarrhationis, donantur, et per eam ad viri domum perferantur, in specie paraphernum, et res paraphernales dicuntur ", citované podl'a KELEMEN, ref. 22, II. Liber, s. 232.

92 KELEMEN, ref. 22, II. Liber, s. 232; FRANK, ref. 34, s. 313.

93 LUBY, ref. 7, s. 325; KÖVY, ref. 22, s. 80-81. 
li, v merôsmych rokoch pre turbulentnost' revolučného pohybu a jeho konečný neúspech nedošlo k nijakým výraznejším právnym premenám. Dôležité však bolo, že nastúpil pozvol'ný dlhotrvajúci rozpad a postupný zánik spoločnost'ou tradične akceptovaného statusu ženy $\mathrm{v}$ dôsledku marcového zákonodarstva roka 1848 v nadväznosti na celoeurópsky politický, sociokultúrny aj ekonomický vývoj. ${ }^{94}$ Prioritnou a všeobecnou požiadavkou novodobého právneho vývoja po roku 1848/49 sa stalo zakotvenie zásady rovnosti, pretavenej nielen, ale aj do rovnoprávneho vzt’ahu oboch pohlaví. Špecifikom uhorského právneho vývoja bolo, že sa tak nestalo formou deklarácie v ústavnej či zákonnej rovine. Naopak, išlo o postupný vývoj likvidácie stavovských výsad a privilégií zväčša rozšírením platnosti noriem šl'achtického práva na zostávajúce širšie skupiny obyvatel'stva. ${ }^{95}$ Ak teda hovoríme o trvaní a kvalite uvedeného emancipačného procesu, je potrebné ho percipovat' cez prizmu jeho výraznej pozvol'nosti, kolísavosti, ambivalentnosti, čo bolo príznačné pre vtedajšiu slovenskú (aj uhorskú) societu, ovládanú konzervativizmom, patriarchálnym vedomím a tradičnou podriadenost'ou ženy. Rovnako je potrebné reflektovat' aj tradične pretrvávajúce rozdiely medzi mestskou a vidieckou komunitou, majúce zásadný vplyv na faktickú pozíciu ženy v rodine a v spoločnosti.

Oblast' súkromnoprávnych vzt'ahov dosiahla prvé významné zmeny v konštrukcii vecných práv a dedičského práva už marcovým zákonodarstvom z roku 1848 (zák. čl. XV/1848), a tiež po vydaní Aviticitného patentu (1852) a následne Dočasnými súdnymi pravidlami Judexkuriálnej konferencie (1861). ${ }^{96}$ Uvedené

94 DUDEKOVÁ - LEGYELOVÁ, ref. 6, s. 60-63.

95 Dedičstvo osvietenstva, individualizmu spolu s vel'kými sociálnymi, ekonomickými, ideovými a demografickými zmenami v spoločnosti, ku ktorým došlo v priebehu 19. a začiatku 20. storočia, narušili tradičné patriarchálne usporiadanie rodiny, s čím sa spájala aj postupná emancipácia žien, rast ich vzdelanostnej úrovne a presadzovanie ich aktívnejšej úlohy nielen v súkromnej sfére (najmä $\mathrm{v}$ tradičnom nukleárnom rodinnom modeli), ale aj vo verejnej sfére (napríklad v boji za politické práva žien). Koncom 19. storočia dochádza na území Slovenska aj k zmene demografického vývoja a k demografickej prevahe žien, spôsobenej nižšou úmrtnost'ou a rastúcim vyst'ahovalectvom. In DUDEKOVÁ - LENGYELOVÁ, ref. 6, s. 61.

V 90. rokoch 18. storočia sa pod vplyvom politizácie verejného života začalo verejne diskutovat' o celospoločenskom význame a potrebe vzdelávania dievčat, ciel'och a zameraní tohto typu školstva. S prvým uceleným pohl'adom na stav a smerovanie dievčenského vzdelávania vystúpil na 16. zasadnutí Školskej deputácie uhorského snemu 29. júla 1791 gróf Anton Brunszvik. Posilnenie významu vzdelávania dievčat sa následne spájalo aj s hodnotami národného obrodenia, ideálom bola budúca matka - vychovávatel'ka detí v národnom duchu. Pozri aj KOWALSKÁ, Eva. Dievčenské vzdelávanie v Uhorsku. In LENGYELOVÁ, ref. 6, s. 178179. Od roku 1895 bolo ženám v Uhorsku sprístupnené štúdium medicíny, farmácie a filozofie.

96 Dočasné súdne pravidlá ako dočasnú právnu smernicu pre uhorské súdy prijala Judexkuriálna konferencia, zvolaná panovníkom v januári 1861. In MOSNÝ, Peter - HUBENÁK, Ladislav. Dejiny štátu a práva na Slovensku. Košice: Aprilla, s.r.o., 2008, s. 101 n. ISBN 
právne normy vo vzt'ahu k právnemu postaveniu ženy deštruovali predovšetkým stredovekú koncepciu tzv. osobitných práv žien, pričom jednotlivé inštitúty boli po prvýkrát kategorizované a systemizované do príslušných právnych odvetví súkromného práva: vecného, rodinného, záväzkového a dedičského práva. Právne postavenie ženy koncom 19. a začiatkom 20. storočia na rozdiel od stredoveku už necharakterizovali osobitné zvýhodnenia a znevýhodnenia ženského pohlavia vymedzované v kontrapozícii s mužmi, ale postupne formulovaný názor o rovnosti pohlaví ešte zatial' nerovnomerne zhmotnený do ustanovení jednotlivých právnych odvetví, pretože k prvej formulácii rovnosti pohlaví na našom území došlo v $§ 106$ Ústavnej listiny ČSR z 29. februára $1920 .{ }^{97}$

Klúčovú zmenu zaznamenalo osobnoprávne postavenie slobodných žien (zrušenie poručníctva nad slobodnými ženami v nadväznosti na dosiahnutie plnoletosti). Zrušenie poručníctva nad plnoletými slobodnými ženami znamenalo, že ako 24-ročné sa podl’a $§ 1$ zák. čl. XXIII/1874 ${ }^{98}$ ženy (t. j. slobodné ženy podliehajúce moci otca alebo poručníka) zo zákona emancipovali, čo v podstate potvrdilo predchádzajúcu novovekú prax. Pred nadobudnutím plnoletosti maloletá žena (ale aj muž) podliehali moci otca alebo poručníka (§ 2 zák. čl. XX/1877 o poručníctve a opatrovníctve).${ }^{99} \mathrm{~K}$ zníženiu vekovej hranice na 21 rokov pre obe pohlavia došlo v období prvej Československej republiky (zákonom č. 447/1919 Zb. z. a n.). Pre ženu však bola ponechaná v historickom vývoji dlhodobo zachovávaná možnost' skoršieho nadobudnutia plnoletosti uzavretím manželstva, ${ }^{100}$

9788089346028. Pozri bližšie aj GÁBRIŠ, Tomáš. Dočasné súdne pravidlá Judexkuriálnej konferencie z roku 1861: monografická štúdia a historickoprávny komentár. Bratislava: Atticum, 2013. ISBN 9788080786014.

97 Východisko rovnosti pohlaví môžeme významnejšie demonštrovat' na zaujímavej prvorepublikovej judikatúre Najvyššieho súdu ČSR v kontrapozícii s praxou súdov nižšieho stupňa týkajúcu sa právneho postavenia ženy. V odôvodnení rozhodnutia Najvyššieho súdu ČSR zo dňa 14. februára 1931, Rv IV 441/30 (Úradná sbierka II, 1930, č. 601) Najvyšší súd ČSR (NS ČSR) odmietol akceptovat' „Všeobecnú zásadu“ vyslovenú súdom nižšieho stupňa, ,podl’a ktorej by manželka nižšieho spoločenského postavenia nemajetná a nevzdelaná spravidla musela preukázat' t’ažši stupeň zlého zaobchádzania manželovho, než manželka z lepšej spoločenskej triedy".

$98 \S 1$ zák. čl. XXIII/1874 o plnoletosti žien ,Slobodné ženy dosiahnutím 24 roku veku sa stanú plnoletými a nadobudnú všetky práva spojené s plnoletostou. “ Išlo o tzv. všeobecnú hranicu plnoletosti rovnakú pre mužov aj pre ženy.

$99 \S 2$ zák. čl. XX/1877 o poručníctve a opatrovníctve: „Maloletí sú pod otcovskou mocou alebo pod poručníctvom. "

$100 \mathrm{Na}$ rozdiel od ženy muž - manžel uzavretím manželstva nenadobúdal plnoletost'. Uvedené ustanovenie bolo v danej dobe predmetom kritiky zo strany právnej vedy a praxe. Pozri napr. RÁTH, Augustín. Práva medzi mužom a ženou v Uhorsku. Praha: Tiskem Aloisa Wiesnera v Praze, 1906, s. 8. K zosúladeniu možnosti skoršieho nadobudnutia plnoletosti uzavretím manželstva pre ženu i pre muža došlo na našom území prijatím prvého spoločného československého Občianskeho zákonníka z roku 1950. Pozri bližšie ŠOŠKOVÁ, Ivana. Veková hra- 
a to po dosiahnutí 16 . roku veku. K manželstvu osoby mladšej ako 20 rokov bol však potrebný súhlas zákonného zástupcu - rodiča alebo poručenskej vrchnosti. ${ }^{101}$ Plnoletost' nadobudnutá uzavretím manželstva sa nestrácala ani v prípade rozluky manželstva či ovdovenia pred dosiahnutím 24 rokov, (a následne 21 rokov).

V oblasti rodinného práva, resp. presnejšie osobných vzt’ahov medzi manželmi hlavou rodiny v zmysle platnej právnej úpravy zostal aj nad’alej manžel $\mathrm{s}$ tým, že vedenie domácnosti bolo právom manželky ${ }^{102}$ (tzv. kl'účna moc). ${ }^{103}$ Manželka už nepodliehala moci manžela ${ }^{104}$ po osobnoprávnej stránke. ${ }^{105}$ Postavenie muža ako hlavy rodiny pretrvalo (prevzal ho aj návrh čsl. Občianskeho zákonníka z roku 1937, § 49) a zmenilo sa až s účinnost'ou zákona o rodinnom práve z roku $1949 .{ }^{106}$ Uzavretím manželstva manželka získala priezvisko manžela a bola povinná nasledovat' manžela do miesta jeho pobytu, súdobá súdna prax bola nejednotná v stanovisku, či mohlo íst' aj o zahraničie. ${ }^{107}$ Žena vždy

nica plnoletosti vo vývoji práva platného na území Slovenska. In Notitiae Novae Facultatis Iuridicae Universitas Matthiae Beli Neosolii, 2011 - 2012, roč. 17, s. 319.

$101 \S 7$ a 8 zák. čl. 31/1894 o manželskom práve. Pozri bližšie aj ŠOŠKOVÁ, Ivana. Plnoletost’ ako predpoklad svojprávnosti v podmienkach 1. ČSR. In Historia et theoria iuris, 2013, roč. 5, č. 1, s. 99. ISSN 1338-0753.

102 Služobníctvo vo všeobecnosti prijímal manžel, avšak služobníctvo pre domácu a vnútornú obsluhu domácnosti prijímala manželka. § 4 zák. čl. XIII/1876 „Čel'ad’ prijímat’ prislúcha $v$ rodinných pomeroch spravidla hlave rodiny, manželovi, avšak čel'ad' $k$ službám v domácnosti a k službám vnútorným môže prijímat' i manželka; ale jestli sa ich názory rozchádzajú, rozhoduje slovo manželovo a on môže pri zachovani zákonitej výpovednej lehoty prepustit' takéhoto služobného zo služby. “

103 Kl'účna moc manželky zahíňala právo spravovat' domácnost' a právo zastupovat' manžela i domácnost' vo vzt’ahu k tretím osobám. LUBY, Kl'účna moc manželky, ref. 39, s. 14.

104 Porovnaj rozh. NS ČSR z 15. januára 1932, Rv III 528/31 (Úradná sbierka, IV. č. 838): , Manželka nie je povinná poslúchnut' vyzvania manželovho, aby obnovila manželské spolužitie, a má proti nemu nárok na výživu, jestli manžel žil po celý rad rokov v konkubináte s inou ženou. "

105 Na výsadné postavenie a isté vyjadrenie vzájomných vzt’ahov medzi manželmi Luby použil termín „neúplná rovnoprávnost'“, ktorý vecne odôvodňuje tým, že dosiahnutím úplnej rovnoprávnosti manželov by bola ohrozená jednota rodiny s vynútením potreby častých súdnych rozhodnutí. LUBY, Klúčna moc manželky, ref. 39, s. 8.

106 Na výsadné postavenie a isté prerogatívy manžela poukázala I. Šošková, ked' manžel ako hlava rodiny bol oprávnený aj povinný starat' sa o hmotnú i osobnú existenciu rodiny a jej ochranu. In ŠOŠKOVÁ, Ivana. Manželstvo a manželsko-právne vzt'ahy vo svetle prvej kodifikácie československého rodinného práva 1949. Banská Bystrica: Belianum, 2016, s. 104-106. ISBN 9788055711515.

107 KNORR, Alajos. Házassági perek és eljárás a házassági perekben. Budapest: Az Athenaeum irod. és nyomdai R.T. Kiadása, 1899, s. 75-76. Porovnaj d'alej rozhodnutie NS ČSR z 21. februára 1931, Rv IV 3/31: „Zvolenie miesta spoločného bydlenia manželského patrí k právom manžela ako hlavy rodiny, vo vykonávani ktorého je obmedzený iba povinnostou brat' 
sledovala domovské právo muža a v prípade ženy cudzinky aj štátnu príslušnost' manžela. ${ }^{108}$

Vo vzt'ahu k det'om žena - matka nedisponovala mocou zodpovedajúcou otcovskej moci (§ 15 zák. čl. XX/1877 o poručníctve a opatrovníctve). ${ }^{109}$ Výsadné postavenie $\mathrm{v}$ oblasti práv $\mathrm{k}$ det’om $\mathrm{v}$ zmysle právnej úpravy mal teda otec - muž. Koncept rodičovskej moci (a rovnoprávnejšia pozícia otca a matky v rodine) sa začala presadzovat' $v$ práve až v polovici 20. storočia (t. j. opätovne až účinnost’ou zákona o rodinnom práve z roku 1949). Výnimkou bol vzt’ah matky k nemanželskému diet'at'u. Zákonnou zástupkyňou nemanželského diet’at’a bola totiž jeho matka, rovnako ako aj vyživovacia povinnost' nemanželského diet'at'a zat'ažovala matku (§ 11 zák. čl. XX/1877 o poručníctve a opatrovníctve). ${ }^{110} \mathrm{~V}$ prípade smrti otca, resp. nemožnosti výkonu jeho práv bola žena - matka prirodzenou a zákonnou poručníčkou ${ }^{111}$ detí (inak bola $\mathrm{z}$ výkonu poručníctva vylúčená) bez povinnosti skladania účtov zo správy majetku.

Vzájomné vzt’ahy medzi manželmi boli aj nad’alej poznačené tradične akceptovanou pozíciou muža ako hlavy rodiny, avšak s postupným presadzovaním rovnoprávneho postavenia manželky. Jedným z prvých impulzov bolo aj zakotvenie dôvodov rozvodu manželstva v zák. čl. XXXI/1894 o manželskom práve. Zároveň zákonný článok XXXI/1894 sa v dobe svojho vzniku chápal ako zásadná reforma vedúca $\mathrm{k}$ presadeniu občianskoprávneho chápania inštitútu manželstva. Úprava obsiahnutá v manželskom zákone zahíňala predovšetkým osobné vzt'ahy medzi manželmi, nie majetkovoprávne, ktoré boli nad’alej rozvíjané obyčajovým právom a súdnou praxou. ${ }^{112}$ Prelomovým zákonným ustanovením bolo zavedenie obligatórnej civilnej formy uzavierania manželstva s tým, že bolo ponechané na rozhodnutí snúbencov, či po uzavretí manželstva civilnou formou uzavrú aj manželstvo podl'a príslušných cirkevných predpisov.

slušný zretel' na rady a námietky manželky. Toto miesto môže byt' podl’a okolností prípadu aj v Amerike“ a rozhodnutie NS ČSR z 15. februára 1933, Rv III 203/32 „Manželka lodníka je povinná nasledovat' svojho manžela i do bydlišta, ktoré je v cudzozemsku, jestli bol tam zamestnávatel'om z úradu preložený. “

$108 \S 5$ a $§ 34$ zák. čl. L/1879 o nadobudnutí a strate uhorského štátneho občianstva.

$109 \S 15$ zák. čl. XX/1877 o poručníctve a opatrovníctve ods. 1 „Otec vykonáva otcovskú moc nad manželským a nad uzákoneným diet'atom. "

110 K zrovnoprávneniu manželských a nemanželských detí došlo na základe zákona č. 265/1949 Zb. o práve rodinnom.

111 Rozh. Král'. Kúrie č. 7625/1891 „Ak niet ani otca ani menovaného poručníka, poručníctvo prejde na matku ako zákonitú a prirodzenú poručničku s tým, že za vdovstva spravuje imanie maloletých detí bez účtovania a len po novom vydaji je povinná účtovat. "

112 Výnimkou bola formulácia vyživovacej povinnosti manžela voči manželke vychádzajúca z konštrukcie dočasného výživného alebo definitívneho výživného (rozsudok o rozluke alebo o separácii od stola a lože) a zohl'adňujúca zavinenie na rozpade manželstva a manželského spolužitia. 
Zákon upravil prekážky manželstva podl’a dovtedy platného kánonického práva s rozdelením manželských prekážok na vylučujúce (pri ktorých bolo manželstvo zo zákona neplatné) a zakazujúce. Zakotvil pomerne komplikovanú úpravu rozvodu (vo vtedajšej terminológii rozluky) manželstva vychádzajúcu z princípu zavinenia. Ponechal v platnosti aj inštitút kánonického práva - separáciu od stola a lože (separatio a thoro et mensa), ktorá nespôsobovala zánik manželstva, ale len zánik povinnosti spoločného manželského života. Osobné vzt’ahy medzi manželmi neboli v zákone striktne formulované, ich obsah bolo možné vyvodit' z charakteru a matérie rozvodových dôvodov. V zákonnej úprave možno badat' presadzovanie prvkov rovnosti pohlaví, avšak spoločenská realita vychádzala ešte stále zo vžitého patriarchálneho modelu, osobitne vo vidieckej societe. Uvedený záver však viac platí o osobnoprávnych vzt’ahoch manželov navzájom a o vzt'ahoch manželov k det'om, na poli majetkových vzt'ahov medzi manželmi sa emancipačný proces (aj vzhl'adom na väčšinové usporiadanie majetkových vzt'ahov medzi manželmi v podobe koakvizície a existujúcu samostatnost' ženy pri disponovaní s jej vlastným majetkom v historickom vývoji) presadil už skôr.

Spoločenský a hospodársky vývoj v 19. storočí si vynútil i novú úpravu majetkových vzt’ahov medzi manželmi, ${ }^{113}$ čo sa prejavilo v poklese významu niektorých inštitútov, ako napr. obvenenie, a naopak v posilnení významu iných inštitútov, ako napr. koakvizícia. Stredoveko-novoveké chápanie obvenenia ako „odmeny za vernost” " v zmysle ustanovení Tripartita sa však udržalo aj v etape budovania novodobého práva $\mathrm{v} 19$. až do 20. storočia, pričom uplatnenie zákonného obvenenia bolo rozšírené aj na nešlachticov. ${ }^{114}$ Obvenenie predstavovalo finančný záväzok manžela, splatný pri zániku manželstva, chápaný ako kompenzácia za správanie manželky „, súlade s manželským životom“. Výška zákonného obvenenia už vychádzala zo zákonnej (nie obyčajovej) úpravy prvých obchodných zákonov, tzv. Wildnerových zákonov z roku 1840 (zák. čl. XVI/1840 o obchodníkoch a zák. čl. XVII/1840 o právnych pomeroch tovární) a zo zákona o konkurze (zák. čl. XXII/1840), ktorý v ustanovení § 85 určil výšku zákonného obvenenia tak pre šlachticov, ako aj pre nešl'achticov, a to sumou 400 zlatých pre magnátov, 200 zlatých pre šlachticov a mešt’anov a 40 zlatých pre nešlachticov. V 20. storočí však už obvenenie ${ }^{115}$ pozvol’ne dospelo do štádia

113 LACLAVÍKOVÁ, ref. 41, s. 154.

114 Dokonca ho možno nájst' aj v návrhoch uhorského občianskeho zákonníka zo začiatku 20. storočia. Rozh. Král'. kúrie zo dňa 17. mája 1910, č. 1268/1910 „Zákonné obvenenie vdovy po meštanovi je rovnaké ako v prípade šlachticov, toto obvenenie je podla § 85 písm. b) zák. čl. XXII/1840 vo výške 200 pengö forintov, teda pri súčasnej hodnote $420 \mathrm{~K}$. "Citované podl'a: LALLOSSEVITS, János - LÁNYI, Márton. A magyar magánjog kézikönyve. Budapest: Grill Károly Könyvkiadóvallalata, 1913, s. 128.

115 ŠOŠKOVÁ, Ivana. Vývoj majetkoprávneho postavenia ženy na Slovensku po roku $1945 \mathrm{~s}$ dôrazom na jej majetkové pomery v manželstve. In LASICOVÁ, Jana (ed.). Sféry ženy: právne, 
postupného desuetudine, ${ }^{116}$ ked’že nezodpovedalo novodobému spoločenskému, kultúrnemu a ekonomickému vývoju. Súdna prax a v nej zhmotnená obyčajová úprava sa však $\mathrm{v}$ danej dobe o obvenení ešte pro forma zmieňovala ako o peňažnom dlhu manžela voči manželke vyplývajúcom zo zákona, pričom finančné vyjadrenie zákonom určeného obvenenia tvorilo pri bývalých magnátoch sumu 800 Kč, resp. pri bývalých zemanoch a mešt’anoch sumu 400 Kč a pri vrstve bývalých poddaných sumu 80 Kč. ${ }^{117}$

Omnoho zásadnejším inštitútom aj s významnou pozíciou v súdnej praxi bol inštitút koakvizície ${ }^{118}$ (pôvodne určenej ako model majetkových vzt’ahov medzi manželmi pre neprivilegované vrstvy). Prvá zákonná úprava koakvizície u poddaných je uvedená v $§ 8$ zákonného článku VIII/1840 o dedičskom práve poddaných, ${ }^{119}$ podl'a ktorej majetok nadobudnutý počas manželstva u poddaných sa chápal ako spolunadobudnutý majetok. Obaja manželia na ňom participovali jednou polovicou i s právom slobodnej dispozície s ňou, čo sa prejavovalo najmä $\mathrm{v}$ testovacej slobode $\mathrm{s}$ koakvizičným $50 \%$ podielom každého z manželov. Zákon osobitne uviedol, že manžel nemá právo manželku z jej patriacej polovice koakvizičného majetku závetom vylúčit'. V prípade, ak manžel alebo manželka zomreli bez zanechania potomkov a bez závetu, koakvizičný podiel zomretého manžela prešiel na pozostalého manžela alebo manželku. ${ }^{120}$ Revolučné zákonodarstvo z roku 1848 sa nedotklo úpravy koakvizície. Dočasné súdne pravidlá (§ 13) úpravu koakvizície opätovne potvrdili a ponechali v platnosti, čo spôsobilo, že sa koakvizícia v oblasti obyčajového práva a súdnej praxe ${ }^{121}$ uplatňovala

politické a ekonomické vedy. Banská Bystrica: Univerzita Mateja Bela; Praha: Sociologický ústav Akadémie vied Českej republiky, 2004, s. 80. ISBN 8080830010.

116 Désuétude je prípadom, ak sa právna norma prestala používat' alebo upadla do zabudnutia, čiže ak je norma obsolétna. PRUSÁK, Jozef. Teória práva. Bratislava: Vydavatel’ské oddelenie Právnickej fakulty UK, 1995, s. 211. ISBN 8071600806.

117 LUBY, Štefan. Základy všeobecného súkromného práva. 3. vydanie pôvodného diela. Šamorín: Heuréka, 2002, s. 220. ISBN 8089122000; ŠOŠKOVÁ, Ivana. Komparatívny pohl’ad na majetkoprávne pomery manželov v slovenskom a českom práve v rokoch 1945 - 1949. In MALÝ, Karel - SOUKUP, Ladislav (eds.). Vývoj práva v Československu v letech 1945 - 1989. Praha: Univerzita Karlova v Praze, Nakladatelství Karolinum, 2004, s. 907. ISBN 8024608634.

118 LACLAVÍKOVÁ, ref. 41, s. 227-228.

119 Pozri aj REBRO, ref. 59, s. 91 a n.; REBRO, Karol. Úprava dedičského práva poddaných v 1. polovici 19. storočia na Slovensku. In Historické štúdie, 1964, roč. X, s. 209 a n.

120 Zák. čl. 8/1840 o dedení poddaných $\S 8$,Ked’že u poddaných majetok počas manželstva spolunadobudnutý rovnako prislúcha každému manželovi, môže o ňom tak jeden ako aj druhý $v$ polovici volne nakladat', a z tejto polovice nemôže muž manželku ani závetom vylúčit', ak však jeden z manželov zomrel bez potomstva a bez závetu, celá koakvizícia pripadne manželovi preživšiemu. "

121 Na spôsoby vysporiadania koakvizície v závetoch mešt’anov Trnavy poukazuje štúdia LAC- 
prevažne v manželstvách bývalých poddaných a mešt’anov. Inštitút koakvizície teda zaznamenal najväčší rozvoj po roku 1861 v súdnych rozhodnutiach (v tzv. ustálenej súdnej praxi Král'ovskej kúrie ako najvyššieho všeobecného uhorského súdneho dvora) s tým, že podmienky na tento rozvoj vytvorilo zrušenie základov stredovekého práva v roku 1848 (najmä zák. čl. XV/1848). Naopak, zákonných zásahov do úpravy inštitútu koakvizície bolo vel’mi málo, ako napr. v zákone o konkurze (zák. čl. XVII/1881) a v Exekučnom poriadku (zák. čl. LX/1881) obsiahnutá ochrana osobitného majetku manželky a jej koakvizičného nároku. Koakvizícia existovala ipso iure ${ }^{122}$ len medzi nešl'achtickými manželmi, ${ }^{123}$ aj tí však mohli koakvizíciu vylúčit' uzavretím manželskej zmluvy, ktorá by regulovala majetkové vzt’ahy medzi manželmi inak. V manželstvách šl’achticov a honoraciorov s prioritným uplatnením systému oddelených majetkov manželov sa koakvizícia uplatnila len v prípadoch: ${ }^{124}$ ak sa strany zmluvne dohodli na koakvizícii v manželskej zmluve, ${ }^{125}$ ak žena - šl'achtičná bola spolunadobúdatel'kou majetku a jej meno bolo uvedené v listine o nadobudnutí majetku (Trip. I/čl. 102). Pri nároku na vydanie polovice spolunadobudnutého majetku nebola rozhodujúcou ani okolnost', z viny ktorej manželskej strany manželstvo zanika$10,{ }^{126}$ ani prípadná nevera manželky, na rozdiel od vyživovacej povinnosti, pri ktorej mali uvedené skutočnosti zásadný význam. Pomerne často sa v súdnej praxi bolo možné totiž stretnút's popieraním práva na vydanie koakvizície naj-

LAVÍKOVÁ, Miriam - ŠVECOVÁ, Adriana. Spolunadobudnutý majetok manželov (koakvizícia), osobitný (výlučný) majetok manželov a ich vyjadrenie v právnom úkone mortis causa - testament (Historickoprávny rozbor vyjadrenia inštitútov spolunadobudnutého a osobitného majetku manželov v testamentoch mešt’anov Trnavy v prvej polovici 19. storočia). In Právny obzor, 2006, roč. 89, č. 4, s. 358-370. ISSN 0032-6984.

122 V manželstvách bývalých poddaných a mešt’anov manželka nepreukazovala existenciu koakvizičného nároku. V literatúre sa však vo vzt’ahu $\mathrm{k}$ mešt’anom vyskytli aj opačné názory (Nánássy, Georch), ktoré však právna veda a ani súdna prax neprevzala. KRÁL, Štefan. Koakvizícia. Martin: Matica Slovenská, 1938, s. 47.

123 „Koakvizícia nastáva len u osôb nešlachtických. “ Rozh. Král'. kúrie č. 549/1906. Citované podl'a ROUČEK, František - SEDLÁČEK, Jaromír. Komentář k čsl. obecnému zákoníku občanskému a občanské právo na Slovensku a v Podkarpatské Rusi. Reprint pưvodního vydání. V. dil. Praha: CODEX Bohemia, 1998, s. 513. ISBN 8085963604.

124 LACLAVÍKOVÁ, Miriam. Spolunadobudnutý majetok manželov (koakvizícia) a formovanie modernej úpravy majetkových vzt’ahov medzi manželmi (1848 - 1950). In SCHELLE, Karel (ed.). Právní a ekonomické problémy současnosti I. Sborník prací. Ostrava: KEY Publishing, s.r.o., 2007, s. 75-76.

125 Rozh. Král'. kúrie č. 7703/1900 „,Medzi osobami šl’achtickými niet koakvizície, vynímajúc, že by bola smluvená, manžel sa tu pokladá za hlavného nabyvatel'a imania. " Citované podl'a ROUČEK - SEDLÁČEK, ref. 123, s. 512.

126 Rozh. Král'. kúrie č. 2097/1897 „,Jestli manželka opustí spoločenstvo s manželom pre jeho násilenstvo, nestráca právo na koakvizíciu “, a rozh. č. 6017/1916 (cit. vyššie). Citované podl'a ROUČEK - SEDLÁČEK, ,ref. 123, s. 513-514. 
mä kvôli manželkinej nevere. V týchto prípadoch najvyšší všeobecný uhorský súd Král'ovská kúria zaujal jednoznačné stanovisko, ktoré priznalo žene právo na koavizíciu, avšak len do zániku koakvizičnej doby. ${ }^{127}$ Koakvizičná doba zanikala vstupom do konkubinátu, ako konštatovala Král'ovská kúria v rozhodnutí č. 6017/1916, podl'a ktorého: „Jestli žena muža, ktorý je dlhé roky v Amerike, vstúpi do konkubinátu, zaniká zárobkové spoločenstvo medzi ňou a jej manželom. " 128 Inštitút koakvizície napriek jeho ,stredovekým koreňom" našiel svoje uplatnenie aj v novodobom práve a v „,modernej industriálnej spoločnosti“ 19. a 20. storočia. Literatúra často zdôrazňuje, že , koakvizícia ekonomicky pozdvihovala ženu ", ktorej ekonomický prínos pre rodinu sa v 19. a 20. storočí viac zhmotňoval. Jej zabezpečovacia funkcia sa plne prejavila pri zániku manželstva, či už inter vivos, alebo mortis causa, ked' bola čast' z bývalého spoločného majetku (konkrétne 1/2 spolunadobudnutého majetku), často zvel'ad'ovaného spoločnou prácou oboch manželov, vydelená samotnej žene alebo vdove. V tomto smere koakvizícia mohla narúšat’ tradičnú predstavu patriarchálnej rodiny s dominantným postavením muža vo vzt’ahu k majetku.

Právny partikularizmus a s ním súvisiaca stavovská podmienenost' uplatňovania jednotlivých právnych noriem sa začali narúšat' v období novoveku, a to nielen v rovine právnej (prvé kodifikácie občianskeho práva), ale aj v rovine sociologickej (predstavy tradičnej, stavovsky vymedzenej rodiny (rodu) v opozícii $\mathrm{s}$ rozvojom l'udských a občianskych práv a prerodom k občianskej spoločnosti). Oblast' manželského majetkového práva však bola v tomto zmysle špecifická a v nej sa viac-menej stavovské rozdiely latentne udržali (osobitne to platí vo vzt’ahu k nášmu územiu, kde ich relikty v oblasti manželského majetkového a dedičského práva môžeme pozorovat’ až do polovice 20. storočia), čo súvisí aj s konzervatívnym, konvenčným postojom a hodnotením manželského a rodinného práva súdobou slovenskou verejnost’ou. Ako pozostatky stavovských rozdielov v oblasti manželského majetkového práva a dedičského práva $\mathrm{v}$ tomto období pretrvali: vdovské dedenie, zákonné obvenenie pre bývalú šl'achtu a odlišné modely usporiadania majetkových vzt’ahov medzi manželmi (koakvizičný systém pre bývalé poddanské vrstvy a mešt’anov; systém oddelených majetkov pre šl'achtu). Predstavené stavovské rozdiely zasahujúce aj do právneho statusu ženy neodstránil ani zákon č. 61/1918 Zb. z. a n., ktorým sa zrušilo šl’achtictvo, rády a tituly (čo potvrdila aj súdna prax), a ani Ústavná listina ČSR č. 121/1920

127 Avšak samotná okolnost', že muž opustil spoločnú domácnost' ,už dlhé roky žije v Amerike, nezrušuje medzi manželmi zárobkové spoločenstvo, jestli manžel odišiel so súhlasom manželky a nie preto, aby prerušil manželské spolužitie“ (rozh. Král'. kúrie č. 4658/1915). Citované podl'a ROUČEK - SEDLÁČEK, ref. 123, s. 514.

128 Rozh. Král. kúrie č. 6017/1916. Citované podl’a ROUČEK - SEDLÁČEK, ref. 123, s. 513-514. 
Zb. z. a n. deklaráciou rovnosti obsiahnutou v § 106, podl'a ktorého ,výsady pohlaví, rodu a povolání se neuznávaji “. K reálnemu odstráneniu predmetných stavovských rozdielov ${ }^{129}$ uplatnenia niektorých inštitútov manželského majetkového a dedičského práva došlo až v druhej polovici 20. storočia všeobecným výkladom ${ }^{130}$ ustanovení Ústavy z 9. mája 1948 o rovnosti všetkých občanov pred zákonom a o rovnakom postavení muža a ženy v rodine i v spoločnosti ${ }^{131} \mathrm{~s}$ prihliadnutím na zmenu spoločenských a politických podmienok. ${ }^{132}$

\section{Záver}

Možnosti a limity regulácie právneho postavenia ženy podliehali a podliehajú dynamickým zmenám vývoja každej spoločnosti. Náš záver pri hodnotení sta-

129 Porovnaj aj všeobecnú čast' dôvodovej správy k Občianskemu zákonníku č. 141/1950 Zb.: „Tento feudálny ráz občianskeho práva platného na Slovensku do roku 1918 zostal v mnohých smeroch zachovaný v právnom poriadku buržuázno-demokratickej Československej republiky ...V majetkovom práve manželskom a v práve dedičskom aplikovaly súdy iné predpisy pre ,honoraciorov 'a iné pre pracujúcich až do vydania Ústavy 9. mája. " Citované podl'a ŠTEFANKO, Jozef (ed.). Prvý občiansky zákoník platný od roku 1951 do roku 1964 s dôvodovou správou a so súvisiacimi predpismi zameranými na vecné právo. Šamorín: Heuréka, 1999, s. 15. ISBN 809676537.

$130 § 171$ ods. 1 Ústavy z 9. mája 1948 „Při výkladu jednotlivých ustanoveni této ústavy je třeba vycházet $z$ ducha tohoto celku a ze zásad, na ktorých je založen." § 171 ods. 2 Ústavy z 9. mája 1948 , Výklad a použivání všech ostatních predpisů právního ř́du bud'tež v souladu s ústavou."

Porovnaj aj GLOS, Jozef - ELIÁŠ, Josef. Rodinné právo. 2. přepracované vydání. Praha: Orbis, 1970, s. 35. „Po vydáni Ústavy 9. května bylo nadále potřeba vykládat a použivat v̌̌echny ostatni predpisy právního řádu vždy v souladu s touto ústavou. V di̊sledku toho se mnoho dosavadnich ustanoveni ... majicich základni význam též pro úpravu právních vztahu $v$ manželstvi a rodině, stalo prakticky nepoužitelnými. Bylo proto naléhavě třeba přikročit k podstatným změnám v právním řádu, vypracovat a vydat nové a dalši právni prededpisy, základni kodexy, odpovídajici stupni vývoje společenských vztahů v našem státě. "

131 § 1 ods. 1 Ústavy z 9. mája 1948 „V̌̌ichni občané jsou si před zákonem rovni. “ § 1 ods. 2 Ústavy z 9. mája 1948 „Muži a ženy maji stejné postaveni v rodině $i$ ve společnosti a stejný př́stup ke vzdělání i ke všem povoláním, úradìm a hodnostem. "

132 Ústava zasiahla aj do oblasti súkromnoprávnych vzt’ahov, v našom prípade do oblasti manželského majetkového práva tak, že platnost' noriem vzt'ahujúcich sa na nešlachticov (bývalých poddaných a mešt’anov), t. j. koakvizícia, bola bez exaktného vyjadrenia $v$ ústave či v inom zákone rozšírená i na bývalých šlachticov a honoraciorov.K tomu porovnaj vystúpenie poslanca Dr. Štefánika (NS RČS, Stenoprotokoly, 37. schôdza, 7. decembra 1949): „,My máme inštitúciu zvanú koakvizícia alebo spolunadobudnutý majetok. U nás táto inštitúcia až do Ústavy 9. mája sa vzt'ahovala na prevažnú väčšinu občanov, neplatila len pre tzv. honoráciorov a bývalých šl'achticov. Od vydania Ústavy 9. mája, ktorou boly nielen na papieri, ale aj $v$ skutočnosti zrušené všetky privilégiá, táto ustanovizeň platí na Slovensku pre všetkých občanov. “ Dostupné na internete: http://www.psp.cz/eknih/1948ns/stenprot/037schuz/s037006. htm [cit. 2014-01-12]. Pozri tiež ŠORL, ref. 67, s. 168; PLANK, Karol. Majetkovoprávne vzt’ahy v rodine. Bratislava: Slovenské Vydavatel'stvo politickej literatúry, 1957, s. 62. 
tusu ženy v staršom práve zohl'adnil zákonmi aj morálkou kánonizovaný paternalizmus voči ženám, tak v pozitívnom aj negatívnom vnímaní, pretože kým právo akceptovalo a fixovalo nerovnost' mužov a žien v ich osobných vzt'ahoch (chápanú ako prirodzený dôsledok rôznosti a rôzneho poslania oboch pohlaví), v oblasti majetkových vzt’ahov sa naopak v mnohom snažilo o korekciu tejto nerovnosti cestou zvýhodnení a protekcionizmu ženského pohlavia.

Vyššie tématizovaný hrubý náčrt identifikoval a pomenoval najzákladnejší právny status ženy $\mathrm{v}$ staršom aj novodobom súkromnom práve, pričom sme si všímali zväčša len preskriptívne, čiže právnymi normami nariadené právne postavenie ženy $\mathrm{v}$ rodinných a majetkových vzt'ahoch. Záverom preto môžeme konštatovat': zmeny v oblasti hospodárskej, sociálnej a demografickej, často spájané s ideálmi občianskych revolúcií 1848/1849 postupne presiakli aj do oblasti tradične konzervatívnej - do fungovania manželstva a rodiny, v ktorej sa realizoval stáročiami formovaný právny a spoločenský status ženy. Pokial' v stavovskej spoločnosti podriadenost' ženy určená biologickými faktormi dotvárala príslušnost' $\mathrm{k}$ stavu, v pozvol'ne klíčiacej občianskej spoločnosti koncom 18. a 19. storočia sa pozostatky nerovnoprávneho postavenia ženy zdôvodňovali už len čisto vedecky a filozoficky. ${ }^{133}$

Realita najmä majetkovoprávnych vzt'ahov však poukázala na zotrvanie istých rezíduí stavovského postavania muža a ženy, a to v zachovaní viacerých na stredovekom práve postavených inštitútov ako bolo vdovské dedenie, obvenenie či veno, dva pôvodné modely usporiadania majetkových vzt'ahov medzi manželmi (dotálny a koakvizičný). Predsa však nová idea právnej a aj mimoprávnej rovnoprávnosti oboch pohlaví ako nový kultúrny fenomén začala narúšat' uplatňujúci sa vžitý model nadradenosti muža, no ako sme už v úvode prejudikovali, išlo o proces postupný a neukončený ani v 40. rokoch 20. storočia. Štefan Luby ${ }^{134}$ konštatuje, že ,princip rovnoprávnosti pohlaví je práve v manželstve a rodine prelomený $v$ prospech manžela, ktorému manželské a rodinné právo priznáva určité prerogatívy “. Nasledujúce 20. storočie v snahe o etablovanie rovnoprávnosti pohlaví či už v rovine súkromnej (intímnej, rodinnej), alebo aj v rovine spoločenskej (verejnej) pokračovalo a, ako sa zdá, aj pokračuje.

133 LENGYELOVÁ, Tünde. Spoločenské postavenie žien v histórii Slovenska. In PISCOVÁ, Magdaléna (ed.). Slovensko na ceste k rodovej rovnosti. Bratislava: ERPA, Sociologický ústav SAV, 2006, s. 39. Zborník dostupný na internete: http://www.sociologia.sav.sk/old/dokument/ equal_rovnost_sk.pdf [cit. 2013-10-17].

134 LUBY, ref. 39, s. 6. 


\section{DER LANGE WEG ZUR RECHTLICHEN EMANZIPATION DER FRAU IN DEN FAMILIEN- UND VERMÖGENSBEZIEHUNGEN}

\section{MIRIAM L A C L A V Í K O V Á - ADRIANA Š V E C O V Á}

Die rechtliche, soziale, ökonomische und sonstige Stellung der Frau ist hinsichtlich der Geschichte auch in Gegenwart noch immer das aktuelle Thema nicht nur aus der Sicht Gender Studies, sondern auch aus der Sicht anderer gesellschaftlichen Wissenschaften, zu denen auch die Rechtswissenschaft und Rechtsgeschichte zählen. Die Autorinnen reflektierten das engere Thema der rechtlichen Emanzipation slowakischer (bzw. ungarischer) Frau im Bereich der Familien- und Vermögensbeziehungen in zwei entwicklungsunterschiedlichen Etappen. Die beiden rechtlichen Beziehungen bilden nämlich den grundlegenden Rechtsrahmen der Stellung jedes menschlichen Einzelwesens, also des Rechts auf den persönlichen Status in der primären gesellschaftlichen Einheit - der Familie und eines der persönlichen Grundrechte - des Rechts auf Eigentum, in dem sich der Mensch realisieren und in dem öffentlichen und privaten Raum auch identifizieren kann.

Die erste Etappe der ursprünglichen Regelung des älteren Rechts hat ihre Grundlage noch im Mittelalter und konservierte sich in der neuzeitlichen Regelung der patriarchalischen Familie und der untergeordneten Rolle der Frauen. In der zweiten Etappe (genannt auch die Zeit des Aufbaus von neuzeitlichem Recht), definiert ungefähr ein Jahrhundert (von 1848 bis 1948), kann man vor allem die Ebene der schrittweisen gesellschaftlich-rechtlichen Gleichberechtigung und Unabhängigkeit der Frauen verfolgen und bemüht sich, die rechtlichen Schlüsselregelungen zu identifizieren, die wichtige Meilensteine auf dem sehr allmählichen und langjährigen Weg zu der verfolgten Frauenemanzipation und Transformation des gesellschaftlichen und rechtlichen Bewusstseins der slowakischen Gesellschaft zusammen gestaltet und konfiguriert haben. Die Studie sollte nur verallgemeinernde Abrisse und die davon resultierenden Folgerungen der Neuschaffung, Judikatur und Rechtswissenschaft über die slowakische Frau vorbringen, die auch ihre gegenwärtige Rechtsstellung formen.

doc. JUDr. Miriam Laclavíková, PhD.

Katedra dejín práva, Právnická fakulta Trnavskej univerzity v Trnave

Kollárova 10, Trnava 91843

e-mail: miriam.laclavikova@truni.sk

doc. JUDr. PhDr. Adriana Švecová, PhD.

Katedra dejín práva, Právnická fakulta Trnavskej univerzity v Trnave

Kollárova 10, Trnava 91843

e-mail: asvecova@truni.sk 
ANNA FUNDÁRKOVÁ

\section{BAROKOVÝ ARISTOKRAT}

